\title{
Aerosol characterization in Northern Africa, Northeastern Atlantic, Mediterranean Basin and Middle East from direct-sun AERONET observations
}

\author{
S. Basart ${ }^{1}$, C. Pérez ${ }^{1, *}$, E. Cuevas ${ }^{2}$, J. M. Baldasano ${ }^{1,3}$, and G. P. Gobbi ${ }^{4}$ \\ ${ }^{1}$ Earth Sciences Department, Barcelona Supercomputing Center-Centro Nacional de Supercomputación, BSC-CNS, \\ Barcelona, Spain \\ ${ }^{2}$ Izaña Atmospheric Research Center, Meteorological State Agency of Spain (AEMET), Santa Cruz de Tenerife, Spain \\ ${ }^{3}$ Environmental Modelling Laboratory, Technical University of Catalonia, Barcelona, Spain \\ ${ }^{4}$ Inst. of Atmospheric Sciences and Climate, ISAC-CNR, Rome, Italy \\ *now at: The Earth Institute at Columbia University, NASA Goddard Institute for Space Studies and The International \\ Research Institute for Climate and Society, New York, USA
}

Received: 23 January 2009 - Published in Atmos. Chem. Phys. Discuss.: 24 March 2009

Revised: 24 September 2009 - Accepted: 9 October 2009 - Published: 3 November 2009

\begin{abstract}
We provide an atmospheric aerosol characterization for North Africa, Northeastern Atlantic, Mediterranean and Middle East based on the analysis of quality-assured direct-sun observations of 39 stations of the AErosol RObotic NETwork (AERONET) which include at least an annual cycle within the 1994-2007 period. We extensively test and apply the recently introduced graphical method of Gobbi and co-authors to track and discriminate different aerosol types and quantify the contribution of mineral dust. The method relies on the combined analysis of the Ångström exponent $(\alpha)$ and its spectral curvature $\delta \alpha$. Plotting data in these coordinates allows to infer aerosol fine mode radius $\left(R_{f}\right)$ and fractional contribution $(\eta)$ to total Aerosol Optical Depth (AOD) and separate AOD growth due to fine-mode aerosol humidification and/or coagulation from AOD growth due to the increase in coarse particles or cloud contamination. Our results confirm the robustness of this graphical method. Large mineral dust is found to be the most important constituent in Northern Africa and Middle East. Under specific meteorological conditions, its transport to Southern Europe is observed from spring to autumn and decreasing with latitude. We observe "pure Saharan dust" conditions to show AOD $>0.7$ (ranging up to 5), $\alpha<0.3$ and $\delta \alpha<0$ corresponding to $\eta<40 \%$ and $R_{f} \sim 0.13 \mu \mathrm{m}$. Small pollution particles are abundant in sites close to urban and industrial areas of
\end{abstract}

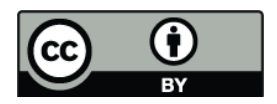

Correspondence to: $\mathrm{S}$. Basart (sara.basart@bsc.es)
Continental and Eastern Europe and Middle East, as well as, important contributions of biomass burning are observed in the sub-Sahel region in winter. These small aerosols are associated to $\mathrm{AOD}<1, \alpha>1.5$ and $\delta \alpha \sim-0.2$ corresponding to $\eta>70 \%$ and $R_{f} \sim 0.13 \mu \mathrm{m}$. Here, dust mixed with fine pollution aerosols shifts the observations to the region $\alpha<0.75$, in which the fine mode contribution is less than $40 \%$.

\section{Introduction}

Aerosols frequently exhibit widely varying optical properties over time due to diffusion and aging processes such as coagulation, humidification, scavenging by precipitation and gas to particle phase conversion (Schuster et al., 2006). These processes, combined with varying source strength and/or advection by local to synoptic meteorological processes, create a dynamic atmospheric constituent affecting climate, environment and public health (IPCC, 2007).

Ground-based aerosol remote sensing does not provide global coverage; however, its numerous spectral measurements of solar radiation are well suited to reliably and continuously derive aerosol optical properties. In spite of high temporal and spatial aerosol variability, there are a rather limited number of general categories of aerosol types with distinctly different optical properties which are associated with different sources and emission mechanisms.

Published by Copernicus Publications on behalf of the European Geosciences Union. 
Aerosol optical depth (AOD) at wavelength $\lambda$ is the standard parameter measured by sunphotometers as those operating in AERONET (Holben et al., 1998). The AOD spectral dependence is mainly driven by the scattering efficiency and can be expressed by means of the classical Ångström's equation $\left(\operatorname{AOD}(\lambda) \sim \lambda^{-\alpha}\right)$ (Ångström, 1929). In the solar spectrum, the Ångström exponent $(\alpha)$ is a good indicator of the dominant size of the atmospheric particles. AOD generated mainly by submicron particles are characterized by $\alpha>1$ whereas supermicron aerosols would lead to $\alpha<1$. As shown in numerous studies (e.g. Eck et al., 1999; Reid et al., 1999; Holben et al., 2001; Dubovik et al., 2002; Smirnov et al., 2002a; Pace et al., 2006; Kaskaoutis et al., 2007), the combined use of the AOD and $\alpha$ allows to distinguish between different aerosol types. As opposite to clean atmospheres $(\mathrm{AOD}<0.15)$ dominated by oceanic aerosols, high values of AOD are characteristic of turbid atmospheres affected by biomass burning, dust plumes or urban pollution (Dubovik et al., 2002). Fluctuations of $\alpha$ reflect aerosol size distribution variations. The maximum value of $\alpha$ (equal to 4) corresponds to molecular extinction. Values near zero (or even negative) correspond to coarse-mode aerosols (sea spray and desert dust) indicating a non-AOD wavelength dependence, while values of $\alpha$ above 1.5 indicate significant presence of fine-mode particles (mainly smoke or urban aerosols). However, different aerosol types may be present in the air column at the same time, influencing the observed optical parameters (Chandra et al., 2004) and resulting into intermediate $\alpha$ values. Remer and Kaufman (1998) showed as well that relative humidity is a determining parameter for the size of aerosol particles. Hygroscopic growth at high relative humidities increases AOD (and reduces $\alpha$ ), due to the enlargement of soluble particles such as sulphates (Levin et al., 1996).

Therefore, $\alpha$ alone does not provide unambiguous information on the relative weight of coarse and fine modes because the optical effects of aerosols are essentially bimodal in nature. In some cases, large fine mode particles can present the same $\alpha$ as a mixture of coarse mode and fine mode particles (Gobbi et al., 2007). Several studies have discussed how the spectral variation of $\alpha$ can provide additional information about the aerosol size distribution (e.g. Kaufman, 1993; Eck et al., 1999; Reid et al., 1999; O'neill et al., 2003; Schuster et al., 2006; Gobbi et al., 2007). In this sense, Kaufman (1993) pointed-out that negative values of the difference $\delta \alpha=\alpha(440,613)-\alpha(613,1003)$ indicate the dominance of fine mode aerosols, while positive differences reflects the effect of two separate particle modes. Eck et al. (1999) showed how, in the wavelength range of 340-870 nm, $\alpha$ can increase by a factor of 3-5 as wavelength increases for biomass burning and urban aerosols, while remaining constant or decreasing in the presence of mineral dust. O'Neill et al. (2001) demonstrated that an Ångström exponent-based separation of coarse from fine mode contribution to AOD is feasible in part because of the coarse mode AOD spectral variation being approximately neutral. Schuster et al. (2006) addressed

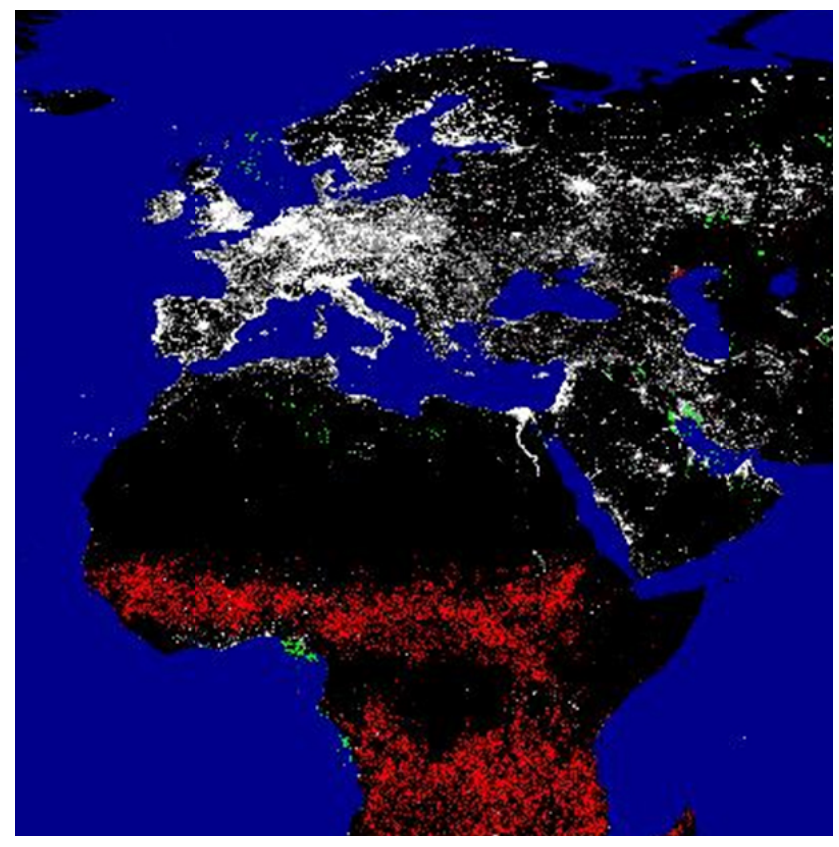

Fig. 1. DMSP Nighttime Lights. Produced using cloud-free portions of low-light imaging data acquired by the US Air Force Defense Meteorological Satellite Program (DMSP) Operational Linescan System (OLS). Four primary types of lights were identified: human settlements - cities, towns, and villages (white), fires (red), gas flares (green), and heavily lit fishing boats (blue). The four types of lights were distinguished from each other based on their appearance, persistence and location. Fires were identified as ephemeral lights on land. Lights from human settlements occur on land and are persistent over time. Gas flares are extremely bright, have a circular appearance, and have no major city present when cross referenced against an atlas. The heavily lit fishing boats are collections of lights found in certain ocean areas and are primarily the result of squid fishing. Date range covers 1 January-31 December 2003. Data analysis and digital image creation by NOAA-NESDISNational Geophysical Data Center-Earth Observations Group Boulder, Colorado USA (http://www.ngdc.noaa.gov/dmsp).

the link between Ångström exponent curvature and the ratio between fine and total aerosol volume. Recently, Gobbi et al. (2007) introduced a straight-forward graphical framework that allows to discriminate different aerosol types based on aerosol spectral measurements by sunphotometers which can be characterized by three independent pieces of information: AOD, $\alpha$ and the spectral curvature of $\alpha(\delta \alpha)$. Plotting data in this space allow for inference of the aerosol fine mode size and fractional contribution to total AOD.

With the possible exception of sea-salt aerosol, mineral dust is globally the most abundant of all aerosol species in the atmosphere (IPCC, 2001). The major sources of contemporary mineral dust are found to be the desert regions of the Northern Hemisphere, in the broad "dust belt" that extends from the eastern subtropical Atlantic eastwards through the Sahara Desert to Arabia and Southwest Asia, 
with remarkably little large-scale dust activity outside this region (Prospero et al., 2002). In the present work, we extensively test the new graphical method introduced by Gobbi et al. (2007) in order to analyze and quantify the contribution of mineral dust to the total aerosol load in Northern Africa, Northeastern Atlantic, Mediterranean Basin and Middle East. Other aerosol types also dominate the atmospheric aerosol load in this region: maritime aerosol, continuously formed over the Mediterranean Sea, the Persian Gulf or the North Atlantic Ocean; fine pollution aerosol mainly originating from urban and industrial areas of Central and Eastern Europe, Middle East and along Nile River (in white and green in Fig. 1); as well as, important contributions of biomass burning generated in Africa mainly in winter (in red in Fig. 1).

This work provides a thorough overview of the aerosols present into our study region and how the aerosol properties are influenced by long-range transport and local sources. Data and methods are described in Sects. 2 and 3. Results are presented in Sect. 4 where we discuss about the main transport paths of desert dust from source areas and their seasonal behaviour, as well as, the variation of its optical properties through the year in each region of the study area.

\section{Measurement data}

Aerosol optical properties in the entire atmospheric column are routinely observed within the AERONET (AErosol RObotic NETwork, Holben et al., 1998) program. This is a federation of ground-based remote sensing aerosol networks established by NASA and LOA-PHOTONS (CNRS) and is greatly expanded by collaborators from national agencies, institutes, universities, individual scientists, and partners. The network consists of more than 500 globally distributed sun and sky-scanning automated radiometers. The standardized network procedures of instrument maintenance, calibration, cloud screening, and data processing allow for quantitative comparison of the aerosol data obtained at different times and locations (Holben et al., 1998; Smirnov et al., 2000).

These instruments can only retrieve data during daytime, because they rely on extinction measurements of the direct and scattered solar radiation at several nominal wavelengths. $(340,380,440,500,675,870$ and $1020 \mathrm{~nm}$ plus a $936 \mathrm{~nm}$ water vapour band). The instrument is out of operation for some weeks while necessary yearly calibration is carried out. Consequently the data coverage in a given station is typically limited to 100-250 days per year. The typical uncertainty in the AOD measured by AERONET instruments ranges from 0.01 to 0.02 and is spectrally dependent with higher errors in the UV spectral range (Holben et al., 1998; Dubovik et al., 2000). This data is provided in three categories: 1 ) raw (level $1.0)$, 2) cloud-screened (level 1.5) following the methodology described by Smirnov et al. (2000), and 3) cloudscreened and quality-assured (level 2.0). However, it is worth

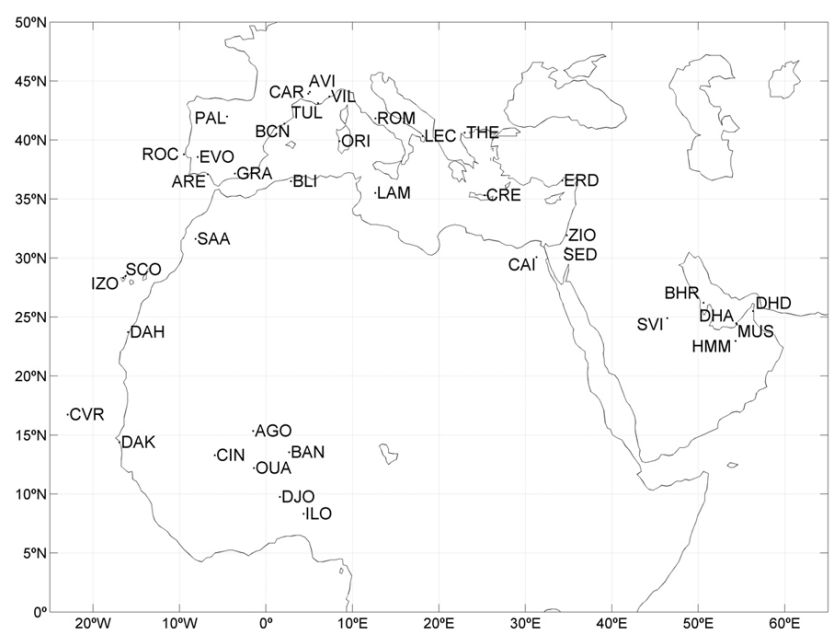

Fig. 2. Spatial distribution of the 39 AERONET stations selected into our study domain. Acronyms are defined in Table 1.

mentioning that some cases of variable aerosol plumes (like intense Saharan dust outbreaks in regions near the desert) could be screened by the cloud-screening algorithm. Conversely, stable uniform cirrus clouds might pass the algorithm thresholds and be identified as cloud free (Smirnov et al., 2000).

Since the goal of this paper is to obtain an aerosol characterization over a large region with standardized measurements, in the present work, quality-assured direct-sun data in the $440-870 \mathrm{~nm}$ wavelength range is used since these channels are highly accurate and they are available in most AERONET instruments. In order to achieve a good temporal coverage, only stations which provided data covering at least the 12 months of the yearly cycle within the 1994-2007 period were chosen. Table 1 and Fig. 2 report the location of the 39 selected AERONET sites. Table 1 lists additional information including type of site, observation periods and percentage of cloud screened data.

\section{Aerosol classification}

In this study we discriminate the fraction of AOD due to large mineral particles from other aerosol types, based on the graphical framework (Fig. 3) introduced in Gobbi et al. (2007) which allows to: 1) infer aerosol fine mode size and fractional contribution to the total AOD; and 2) separate AOD increases due to fine-mode aerosol humidification from AOD increases due to the increase in coarse particles. The method relies on the combined analysis of $\alpha$ derived for the wavelength pairs of $440-870 \mathrm{~nm}$ and its spectral curvature, represented by $\delta \alpha=\alpha(440,675)-\alpha(675,870)$. For the definition of these coordinates ( $\delta \alpha$ vs. $\alpha$ space or AdA coordinates), reference points corresponding to bimodal size distributions characterized by a fine mode modal radii $\left(R_{f}\right.$; solid 


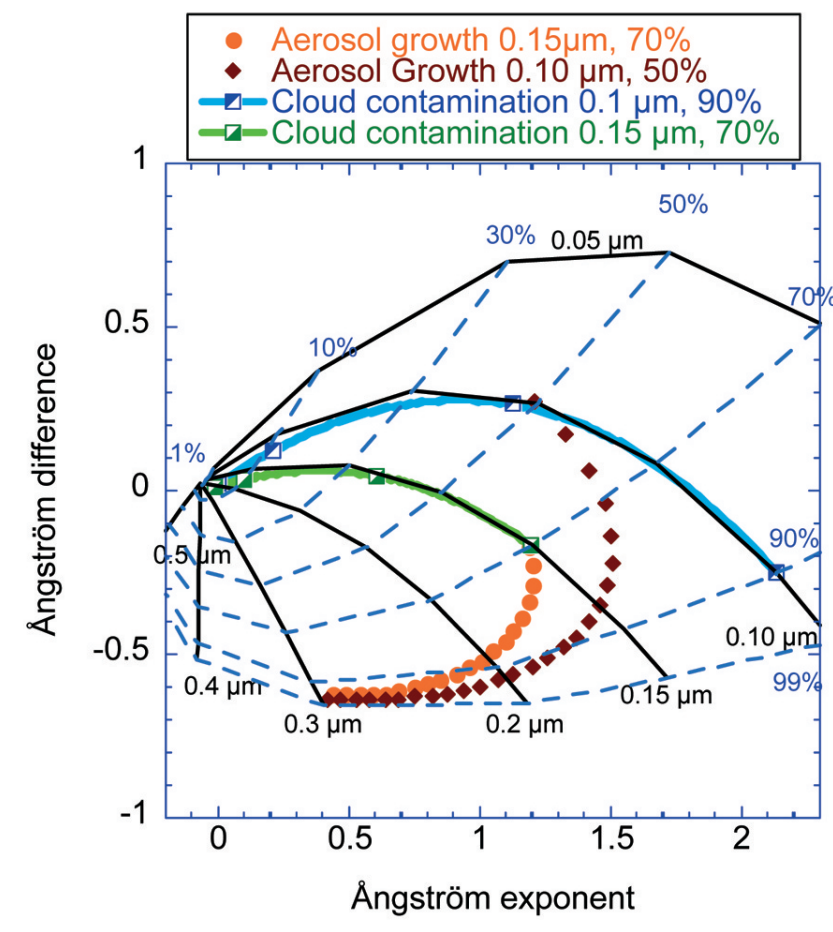

Fig. 3. Simulations of the classification of the aerosol properties as a function of the Ångström exponent $\alpha(440,870)$ and the difference $\delta \alpha=\alpha(440,675)-\alpha(675,870)$, for bimodal, lognormal size distributions with refractive index $\mathrm{m}=1.4-0.001 \mathrm{i}$ extracted from Gobbi et al. (2007). The black solid lines are each for a fixed size of the fine mode $R_{f}$ and the dashed blue lines for a fixed fraction contribution $\eta$ of the fine mode to the AOD at $675 \mathrm{~nm}$. Split squares represent the effects of a cloud contamination of $0,50,90$ and $99 \%$ in the AOD of two grid points initially ( $0 \%$ contamination) located at: 1) $\eta=70 \%, R_{f}=0.15 \mu \mathrm{m}$ (bright green line) and 2) $\eta=90 \%$, $R_{f}=0.1 \mu \mathrm{m}$ (turquoise line). This contamination results in a departure from the original grid points along the constant $\mathbf{R}_{f}$ lines and towards the origin. Conversely, hydration of the aerosol fine mode (two starting conditions simulated: 1) $\eta=50 \%, R_{f}=0.1 \mu \mathrm{m}$ (brown diamonds), and 2) $\eta=70 \%, R_{f}=0.15 \mu \mathrm{m}$ (orange circles)) is accompanied by a movement towards the origin along the opposite direction, with concurrent increase in $R_{f}$ and $\eta$.

black lines in Fig. 3) as well as the ratio of fine mode to total AOD ( $\eta$; dashed blue lines in Fig. 3 ) have been determined on the basis of typical refractive index of urban/industrial aerosol $(\mathrm{m}=1.4-0.001 \mathrm{i})$. Varying coarse mode modal radii have been considered and shown to have a minor impact on such reference points. The level of indetermination of this classification scheme is of the order of $25 \%$ for $R_{f}$ and $\sim 10 \%$ for $\eta$ for refractive index varying between $\mathrm{m}=1.33$ $0.0 \mathrm{i}$ and $\mathrm{m}=1.53-0.003 \mathrm{i}$. Within this level of indetermination, the scheme is robust enough to provide an operational classification of the aerosol properties.

In this space, we represent AOD (at $675 \mathrm{~nm}$ ) by a colour scale. In order to avoid errors larger than $\sim 30 \%$ in the calculation of $\delta \alpha$, only $\mathrm{AOD}>0.15$ are considered. Both aging and humidification of pollution aerosol, and cloud contamination could decrease $\alpha$. However, these processes behave quite differently in the AdA coordinates, as shown in Fig. 3. Cloud contamination is associated to concurrent increase in AOD and coarse mode fraction taking place along constant $R_{f}$ curves (bright green and turquoise lines), while hydration leads to a growth in both $R_{f}$ and $\eta$ (brown diamonds and orange circles). In general, growth of AOD along $R_{f}$ lines means an increase in coarse particle extinction. If cloud screening is efficient, only dust particles or maritime aerosols can cause AOD growth along $R_{f}$ curves.

Recently, O'Neill (2009) showed that these families of contour lines in the AdA space are essentially discretized illustrations of analytical parabolic forms in the space formed by the continuously differentiable Ångström exponent $(\alpha)$ and its spectral derivative $\left(\alpha^{\prime}\right)$. As shown in O'Neill et al. (2003), these variables permit the spectral discrimination of coarse and fine mode optical depth from the spectral shape of AOD by means of a spectral algorithm (O'Neill et al., 2001). The O'Neill fine mode AOD products obtained from direct sun measurements are available in the AERONET website for the Level 1.0 and Level 1.5 data.

In order to check the confidence of $\eta$ retrieved with the graphical method used in the present work with respect to other inversion algorithms, we performed a comparison against O'Neill fine mode algorithm (O'Neill et al., 2003) products and Dubovik's sky-radiance fine mode inversion products (Dubovik and King, 2000; Kinne et al., 2009) of AERONET. Daily $\eta$ averages over one year (2004) for several stations included into our study domain were plotted in the AdA space used in our analysis (see Fig. 4). Results show good coincidence among the three methods in the coarse particle detection ( $\eta<40 \%$; see AGO site in Fig. 4) as well at high $\eta$ values (see ERD site in Fig. 4). Although in some "mixed" stations such as LAM (see LAM site in Fig. 4), some discrepancies appear in $\eta$ values, the differences are always $<20 \%$. These discrepancies are partly due to differences between the measurement frequencies of each dataset (i.e. less frequent sky radiances inversions with respect to direct-sun measurements) (Holben et al., 1998; Dubovik and King, 2000). As expected, the comparison shows a better agreement of the Gobbi's graphical method with O'Neill $\eta$ values (see top panels in Fig. 4) since the outputs of the Gobbi's graphical method are a subset of the products retrieved from the O'Neill algorithm (O'Neill et al., 2009). Somewhat larger discrepancies observed with respect to the Dubovik's sky-radiance inversion products (see bottom panels in Fig. 4) are likely due to the current Dubovik inversion output which is equivalent to what the community refers to as sub-micron fraction as opposed to the spectral deconvolution algorithm output (O’Neill et al., 2005). 
Table 1. Description of the selected AERONET stations. Class of location which are defined as stations: above $1000 \mathrm{~m}(\mathrm{H})$, in arid and desert areas (D), in the ocean (O), in remote and urban areas (R/U) and in littoral areas (C); first and last measurement date, the number of total measurements (Dataset), the number of days $(\mathrm{N})$ and months (Mo.) in the observation periods as well as the percentage of cloud screened data $(\mathrm{C})$ and the percentage of observations with $\mathrm{AOD}<0.15$ with respect to the total number of measurements (B) of the selected AERONET stations.

\begin{tabular}{|c|c|c|c|c|c|c|c|c|c|}
\hline AERONET site & CODE & Class & First data & Last data & Dataset & $\mathrm{N}$ & Mo. & $\mathrm{C}(\%)$ & $\mathrm{B}(\%)$ \\
\hline \multicolumn{10}{|l|}{ North-Western Africa } \\
\hline Agoufou & AGO & $\mathrm{D}$ & $25 / 09 / 2003$ & $31 / 05 / 2007$ & 39530 & 1147 & 45 & 30.88 & 12.28 \\
\hline Banizoumbou & BAN & $\mathrm{D}$ & $16 / 10 / 1995$ & 05/07/2007 & 77529 & 2575 & 108 & 36.20 & 13.48 \\
\hline Capo Verde & CVR & $\mathrm{O}$ & 21/10/1994 & $11 / 04 / 2007$ & 46216 & 2496 & 125 & 39.29 & 26.21 \\
\hline Dahkla & DAH & $\mathrm{R} / \mathrm{UC}$ & $13 / 02 / 2002$ & $05 / 11 / 2003$ & 18789 & 563 & 22 & 25.70 & 52.60 \\
\hline Dakar & DAK & $\mathrm{R} / \mathrm{UC}$ & 04/12/1996 & $12 / 10 / 2006$ & 38454 & 1387 & 69 & 33.91 & 10.48 \\
\hline Djougou & DJO & $\mathrm{R} / \mathrm{U}$ & $24 / 02 / 2004$ & $07 / 05 / 2007$ & 22012 & 819 & 36 & 34.99 & 2.43 \\
\hline IER Cinzana & CIN & $\mathrm{D}$ & $01 / 06 / 2004$ & $26 / 05 / 2007$ & 33207 & 971 & 36 & 31.09 & 10.09 \\
\hline Ilorin & ILO & $\mathrm{R} / \mathrm{U}$ & 25/04/1998 & $27 / 05 / 2006$ & 23556 & 1307 & 66 & 38.45 & 5.00 \\
\hline Izana & IZO & $\mathrm{HO}$ & $17 / 06 / 1997$ & $16 / 10 / 2006$ & 26993 & 690 & 31 & 37.51 & 85.48 \\
\hline Ouagadougou & OUA & $\mathrm{D}$ & $01 / 01 / 1995$ & $15 / 03 / 2005$ & 44820 & 1779 & 74 & 38.20 & 11.55 \\
\hline Saada & SAA & $\mathrm{D}$ & $01 / 07 / 2004$ & $02 / 06 / 2006$ & 19512 & 509 & 21 & 25.64 & 45.15 \\
\hline Santa Cruz Tenerife & $\mathrm{SCO}$ & $\mathrm{O}$ & $15 / 07 / 2005$ & $07 / 05 / 2007$ & 11487 & 449 & 23 & 36.40 & 63.99 \\
\hline \multicolumn{10}{|c|}{ Iberian Peninsula and Mediterranean Basin } \\
\hline Avignon & AVI & $\mathrm{R} / \mathrm{U}$ & 08/12/1999 & $26 / 06 / 2006$ & 41605 & 1548 & 77 & 33.84 & 75.11 \\
\hline Barcelona & $\mathrm{BCN}$ & $\mathrm{R} / \mathrm{UC}$ & $16 / 12 / 2004$ & $24 / 05 / 2006$ & 9457 & 357 & 18 & 37.60 & 68.35 \\
\hline Blida & BLI & $\mathrm{R} / \mathrm{UC}$ & $30 / 10 / 2003$ & $16 / 11 / 2006$ & 15573 & 701 & 37 & 33.94 & 54.70 \\
\hline Cabo da Roca & ROC & $\mathrm{R} / \mathrm{UC}$ & $10 / 12 / 2003$ & $27 / 02 / 2007$ & 11774 & 551 & 32 & 37.14 & 77.31 \\
\hline Cairo EMA & CAI & $\mathrm{R} / \mathrm{U}$ & $13 / 04 / 2005$ & $23 / 03 / 2006$ & 5012 & 269 & 12 & 54.79 & 21.85 \\
\hline Carpentras & CAR & $\mathrm{R} / \mathrm{U}$ & $18 / 02 / 2003$ & $24 / 10 / 2007$ & 35308 & 1177 & 54 & 33.93 & 74.42 \\
\hline El Arenosillo & ARE & $\mathrm{R} / \mathrm{UC}$ & $16 / 02 / 2000$ & $12 / 06 / 2006$ & 39380 & 1344 & 61 & 26.75 & 76.63 \\
\hline Evora & EVO & $\mathrm{R} / \mathrm{U}$ & 03/07/2003 & 09/07/2006 & 24470 & 749 & 34 & 28.33 & 81.27 \\
\hline Forth Crete & CRE & $\mathrm{R} / \mathrm{UC}$ & $04 / 01 / 2003$ & $06 / 11 / 2006$ & 33625 & 1072 & 47 & 23.65 & 66.48 \\
\hline Granada & GRA & $\mathrm{R} / \mathrm{U}$ & $29 / 12 / 2004$ & $11 / 11 / 2007$ & 20882 & 631 & 29 & 32.75 & 69.77 \\
\hline IMC Oristano & ORI & $\mathrm{R} / \mathrm{UC}$ & $30 / 05 / 2000$ & $21 / 10 / 2003$ & 24251 & 934 & 42 & 26.70 & 70.16 \\
\hline IMS-METU-Erdemli & ERD & $\mathrm{R} / \mathrm{UC}$ & $12 / 11 / 1999$ & 03/05/2006 & 34910 & 1218 & 57 & 24.23 & 55.32 \\
\hline Lampedusa & LAM & $\mathrm{R} / \mathrm{UC}$ & $27 / 06 / 2000$ & $12 / 06 / 2006$ & 17361 & 813 & 39 & 22.46 & 65.65 \\
\hline Lecce University & LEC & $\mathrm{R} / \mathrm{UC}$ & 08/03/2003 & $28 / 11 / 2006$ & 26361 & 988 & 42 & 32.04 & 62.78 \\
\hline Nes Ziona & $\mathrm{ZIO}$ & $\mathrm{R} / \mathrm{U}$ & $24 / 02 / 2000$ & $21 / 11 / 2006$ & 42077 & 1577 & 72 & 31.08 & 54.90 \\
\hline Palencia & PAL & $\mathrm{R} / \mathrm{U}$ & $23 / 01 / 2003$ & $24 / 05 / 2006$ & 22220 & 796 & 39 & 32.48 & 86.75 \\
\hline Rome Tor Vergata & ROM & $\mathrm{R} / \mathrm{U}$ & $15 / 02 / 2001$ & $20 / 12 / 2006$ & 33773 & 1310 & 62 & 35.24 & 71.40 \\
\hline Sede Boker & SED & $\mathrm{D}$ & 25/01/1996 & $20 / 10 / 2007$ & 80901 & 2549 & 110 & 27.96 & 66.18 \\
\hline Thessaloniki & THE & $\mathrm{R} / \mathrm{UC}$ & 03/09/2005 & $06 / 05 / 2007$ & 12883 & 426 & 21 & 30.09 & 54.73 \\
\hline Toulon & TUL & $\mathrm{R} / \mathrm{UC}$ & $15 / 11 / 2004$ & $16 / 05 / 2007$ & 20054 & 703 & 31 & 32.97 & 80.34 \\
\hline Villefranche & VIL & $\mathrm{R} / \mathrm{UC}$ & $07 / 01 / 2004$ & $19 / 01 / 2007$ & 19431 & 643 & 31 & 32.45 & 69.45 \\
\hline \multicolumn{10}{|c|}{ Middle East } \\
\hline Bahrain & BHR & $\mathrm{R} / \mathrm{UC}$ & 23/07/1998 & $02 / 10 / 2006$ & 28936 & 1117 & 49 & 23.71 & 17.86 \\
\hline Dhabi & DHA & $\mathrm{R} / \mathrm{UC}$ & 05/10/2003 & $30 / 09 / 2007$ & 27601 & 791 & 30 & 27.18 & 12.81 \\
\hline Dhadnah & DHD & $\mathrm{R} / \mathrm{UC}$ & $28 / 06 / 2004$ & $21 / 09 / 2007$ & 40494 & 1046 & 40 & 22.29 & 15.37 \\
\hline Hamim & HMM & $\mathrm{D}$ & $22 / 06 / 2004$ & 07/08/2007 & 27094 & 876 & 37 & 23.73 & 19.36 \\
\hline Mussafa & MUS & $\mathrm{R} / \mathrm{UC}$ & $04 / 10 / 2004$ & $14 / 03 / 2006$ & 17892 & 480 & 18 & 30.19 & 14.49 \\
\hline Solar Village & SVI & $\mathrm{D}$ & $22 / 02 / 1999$ & $12 / 11 / 2006$ & 87802 & 2259 & 87 & 24.00 & 25.19 \\
\hline
\end{tabular}



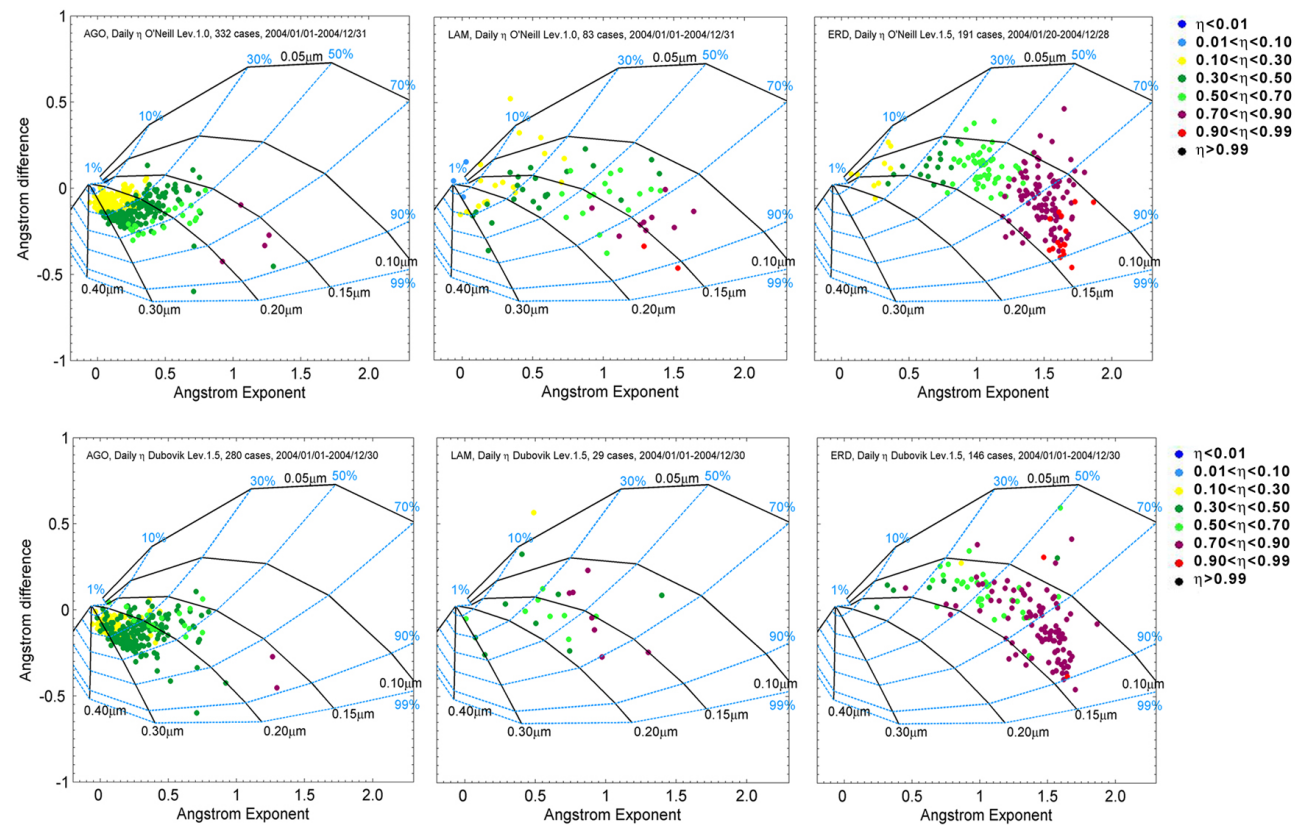

Fig. 4. Daily Fine Mode Fraction ( $\eta$ ) averages for AGO, LAM and ERD stations. For each station, daily $\eta$ averages (color code) obtained by O'Neill inversion algorithm (top panels) and daily $\eta$ averages obtained by means of sky Dubovik inversion products (bottom panels) are plotted in the AdA space using the daily $\alpha$ and $\delta \alpha$ average calculated from direct-sun observations. In all the plots, only daily $\eta$ averages associated to daily AOD $>0.15$ are shown.

\section{Results and discussion}

The classification scheme is applied to the 39 AERONET stations considered in this study. Results for fifteen representative locations are reported in Fig. 5 (BAN, ILO, SAA, CVR, IZO, ARE, AVI, ORI, BLI, LAM, ROM, THE, ZIO, MUS and HMM). Seasonal average behaviour is represented in Figs. 6 and 7 as well as in Table 2. Figure 6 includes the mean seasonal AOD, $\alpha$ and $\delta \alpha$ for all available measurements with $A O D>0.15$. Since the emphasis of the study is on coarse-mode mineral particles, the bias introduced by the $\mathrm{AOD}>0.15$ filter is not expected to be so important. In fact, AODs associated to dust conditions are usually higher (Dubovik et al., 2002). In Table 1, the percentage of measurements associated to $\mathrm{AOD}<0.15$ is shown. The larger percentages $(>60 \%)$ are found in stations located in the Eastern Sub-Tropical North Atlantic, Iberian Peninsula and around the Mediterranean Basin where the presence of coarse-mode mineral dust is sporadic and maritime aerosols are the main aerosol constituent. Figure 7 and Table 2 refer to the coarseparticle fraction of the data which includes all data with AOD $>0.15$ and $\alpha<0.75$. As we show along the present section, pure coarse aerosols in the AdA space are always observed in the region $\alpha<0.75$ in which the fine mode contribution is always $<40 \%$. Figure 7 depicts the seasonal fraction of the number of coarse mode measurements (with AOD $>0.15$ and $\alpha<0.75$ ) with respect to total number of measurements with $\mathrm{AOD}>0.15$. Table 2 shows the mean seasonal contribution to AOD, and $\alpha$ and $\delta \alpha$ average of the coarse mode data (with AOD $>0.15$ and $\alpha<0.75$ ). As shown in the literature (e.g. Kaufman, 1993), strong negative values of $\delta \alpha$ (between -0.5 and -0.2 ) indicate dominance of fine mode aerosols. We have found that under the dominance of coarse mode aerosols, such as desert dust, $\delta \alpha$ tends to be negative or slightly positive (between -0.3 and 0.1 ). In this respect, it is the value of $\alpha$ that allows to define which is the dominating fraction.

\subsection{Sahara-Sahel}

There are relatively few measurements at Sahelian sites (AGO, BAN, CIN, DAK, OUA, DJO, and ILO) during summer when maximum rainfall and cloud cover occur. A larger number of measurements are observed in the winter or dry season. These stations located southward of Saharan sources show large variations of AOD and high extinctions ( $\sim 85 \%$ of the AOD values are above 0.15 with AOD maxima $>4$ ); $\alpha$ is almost inversely-proportional to AOD, and $\delta \alpha$ is negative or slightly positive (ranging between -0.3 and 0.1 , e.g. BAN in Fig. 5) which indicates that AOD increases are often related to an increase in particle size due to desert dust outbreaks or local dust resuspension. High extinction values (AOD $>1$ ) are related to large particles with $\alpha<0.3$ and $\delta \alpha<0$ that corresponds to $\eta<40 \%$ and $R_{f} \sim 0.3 \mu \mathrm{m}$ which are assumed to be typical of pure desert dust conditions. 

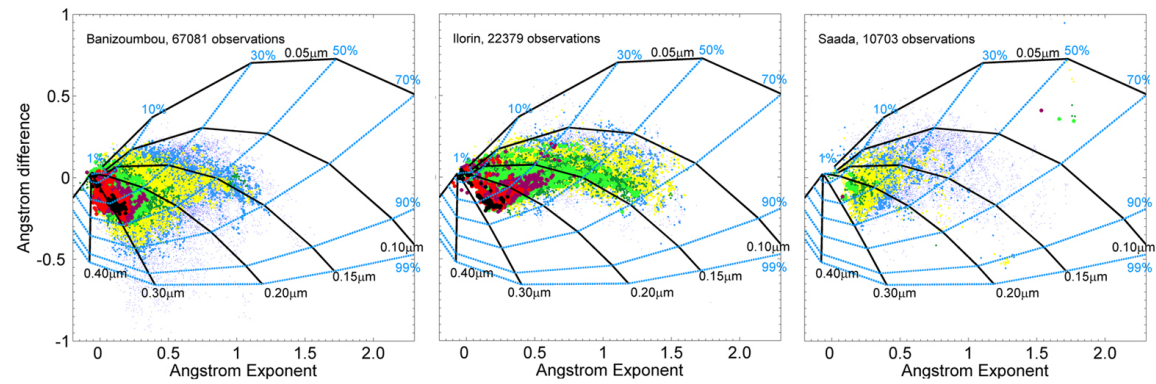

$0.15>A O D<0.3$

$0.3>A O D>0.4$
$0.4>A O D>0.7$

- $0.7>A O D>1.0$

$1.0>\mathrm{AOD}>1.5$
$1.5>\mathrm{AOOD}>2$

- $2>A O D>3$
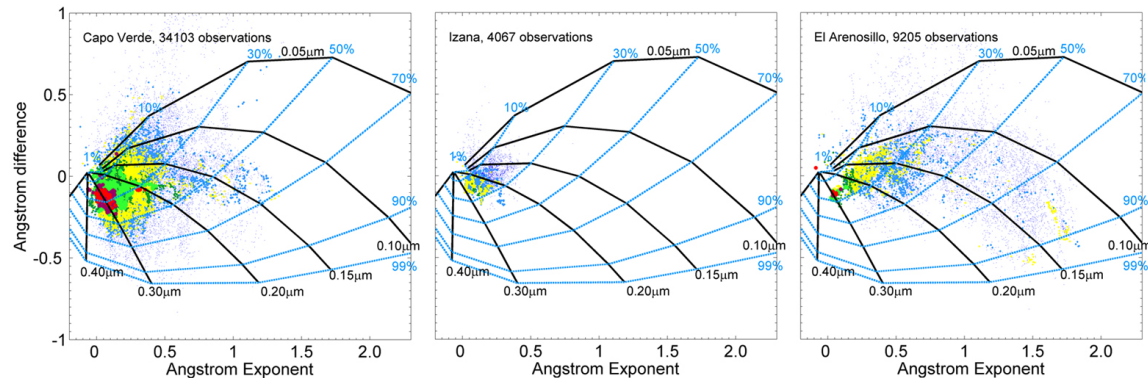

$0.15>A O D<0.3$

$0.3>A O D>0.4$

$1.0>A O D>1.5$

$\cdot 1.5>\mathrm{AOD}>2$

$\because 2>A O D>3$
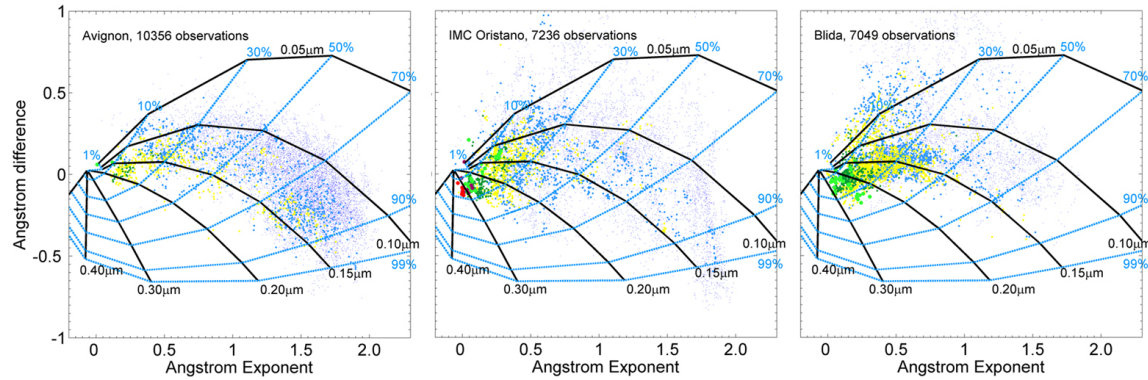

$0.15>A O D<0.3$

$0.3>A O D>0.4$

$0.4>A O D>0.7$

- $1.0>A O D>1.5$

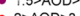

: $A O D>3$
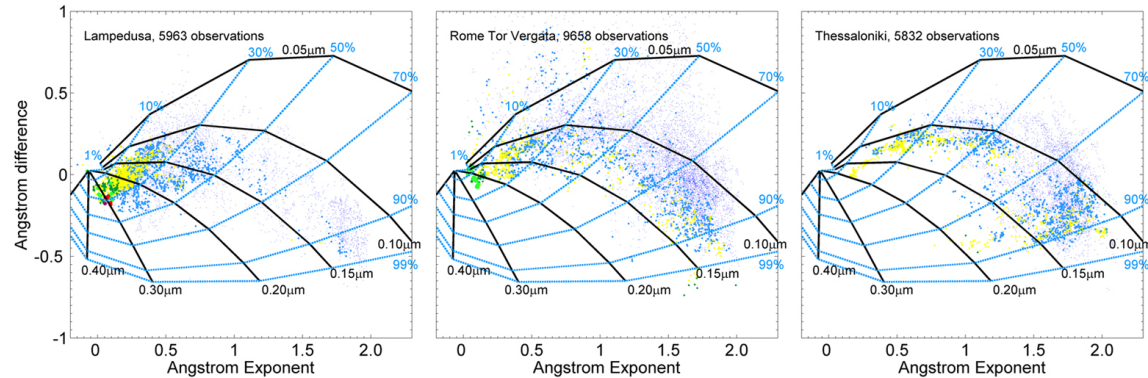

$0.15>A O D<0.3$

$0.3>A O D>0.4$

$0.4>A O D>0.7$

$1.0>A O D>1$.
$-1.5>A O D>2$

- $2>A O D>3$

- $A O D>3$
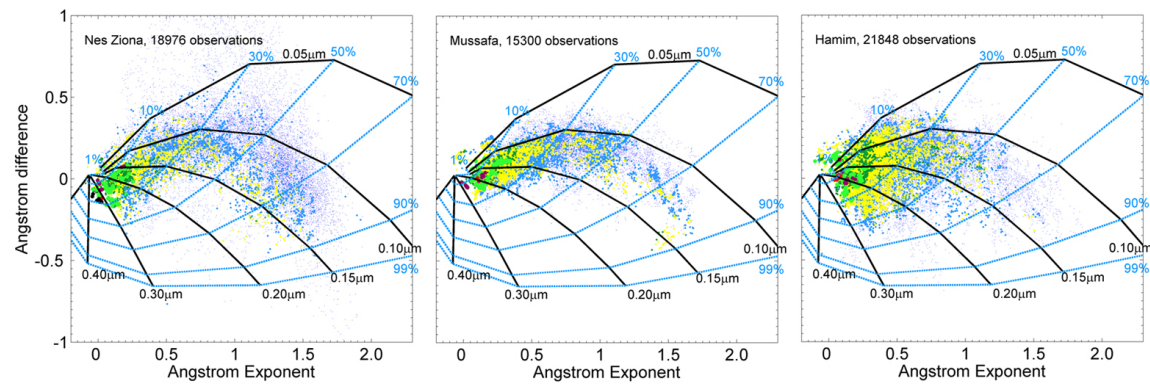

$0.15>A O D<0.3$

$0.3>A O D>0.4$

- $0.7>A O D>1.0$

- $1.0>A O D>1.5$

- $1.5>A O D>2$

- $2>A O D>3$

Fig. 5. Ångström exponent difference, $\delta \alpha=\alpha(440,675)-\alpha(675,870)$, as a function of the $440-870 \mathrm{~nm}$ Ångström exponent and AOD at $675 \mathrm{~nm}$ (color code) for fifteen AERONET stations (from top): BAN, ILO, SAA, CVR, IZO, ARE, AVI, ORI, BLI, LAM, ROM, THE, ZIO, MUS and HMM. 
Table 2. Seasonal mean of AOD at $675 \mathrm{~nm}$, Ångström exponent calculated between 440 and $870 \mathrm{~nm}(\alpha)$ and the Ångström exponent difference, $\delta \alpha=\alpha(440,675)-\alpha(675,870)$, of large aerosols fraction (corresponding to particles with AOD $>0.15$ and $\alpha<0.75$ ) of each AERONET site.

\begin{tabular}{|c|c|c|c|c|c|c|c|c|c|c|c|c|}
\hline \multirow[b]{2}{*}{ Station } & \multicolumn{3}{|c|}{ Winter } & \multicolumn{3}{|c|}{ Spring } & \multicolumn{3}{|c|}{ Summer } & \multicolumn{3}{|c|}{ Autumn } \\
\hline & AOD & $\alpha$ & $\delta \alpha$ & AOD & $\alpha$ & $\delta \alpha$ & $\mathrm{AOD}$ & $\alpha$ & $\delta \alpha$ & AOD & $\alpha$ & $\delta \alpha$ \\
\hline \multicolumn{13}{|c|}{ North-Western Africa } \\
\hline AGO & 0.45 & 0.34 & -0.12 & 0.63 & 0.17 & -0.13 & 0.65 & 0.14 & -0.07 & 0.38 & 0.32 & -0.11 \\
\hline BAN & 0.44 & 0.36 & -0.14 & 0.73 & 0.19 & -0.11 & 0.52 & 0.22 & -0.02 & 0.42 & 0.35 & -0.09 \\
\hline CVR & 0.38 & 0.24 & -0.07 & 0.41 & 0.27 & 0.01 & 0.50 & 0.19 & 0.00 & 0.40 & 0.23 & -0.08 \\
\hline DAH & 0.39 & 0.29 & -0.06 & 0.33 & 0.37 & -0.01 & 0.51 & 0.27 & -0.02 & 0.47 & 0.27 & -0.05 \\
\hline DAK & 0.39 & 0.40 & -0.06 & 0.48 & 0.27 & -0.03 & 0.57 & 0.20 & -0.02 & 0.42 & 0.36 & -0.03 \\
\hline DJO & 0.77 & 0.47 & -0.03 & 0.77 & 0.30 & 0.00 & 0.51 & 0.36 & 0.11 & 0.53 & 0.42 & 0.06 \\
\hline CIN & 0.43 & 0.39 & -0.05 & 0.62 & 0.22 & -0.09 & 0.53 & 0.21 & 0.01 & 0.34 & 0.39 & -0.03 \\
\hline ILO & 1.01 & 0.49 & -0.01 & 0.68 & 0.33 & 0.01 & 0.43 & 0.39 & 0.05 & 0.50 & 0.51 & 0.01 \\
\hline IZO & 0.16 & 0.21 & -0.01 & 0.29 & 0.20 & -0.01 & 0.26 & 0.16 & 0.00 & 0.25 & 0.15 & 0.01 \\
\hline OUA & 0.45 & 0.38 & -0.10 & 0.64 & 0.25 & -0.07 & 0.43 & 0.32 & -0.13 & 0.45 & 0.43 & -0.12 \\
\hline SAA & 0.30 & 0.33 & 0.18 & 0.38 & 0.42 & 0.05 & 0.34 & 0.40 & -0.02 & 0.33 & 0.33 & 0.00 \\
\hline $\mathrm{SCO}$ & 0.21 & 0.43 & -0.09 & 0.43 & 0.37 & 0.02 & 0.37 & 0.33 & 0.06 & 0.33 & 0.32 & 0.03 \\
\hline \multicolumn{13}{|c|}{ Iberian Peninsula and Mediterranean Basin } \\
\hline AVI & 0.33 & 0.45 & 0.25 & 0.32 & 0.52 & 0.16 & 0.35 & 0.50 & 0.14 & 0.35 & 0.48 & 0.14 \\
\hline $\mathrm{BCN}$ & 0.31 & 0.50 & 0.06 & 0.30 & 0.52 & 0.11 & 0.38 & 0.58 & 0.20 & 0.27 & 0.43 & 0.17 \\
\hline BLI & 0.19 & 0.41 & 0.29 & 0.37 & 0.43 & 0.19 & 0.44 & 0.40 & 0.11 & 0.28 & 0.41 & 0.09 \\
\hline $\mathrm{ROC}$ & 0.23 & 0.34 & 0.14 & 0.29 & 0.32 & 0.15 & 0.43 & 0.37 & 0.10 & 0.25 & 0.37 & 0.23 \\
\hline CAI & 0.35 & 0.40 & 0.15 & 0.47 & 0.37 & 0.06 & 0.37 & 0.51 & 0.09 & 0.31 & 0.59 & 0.20 \\
\hline CAR & 0.27 & 0.56 & 0.34 & 0.32 & 0.51 & 0.16 & 0.33 & 0.45 & 0.11 & 0.35 & 0.49 & 0.20 \\
\hline ARE & 0.27 & 0.47 & 0.20 & 0.35 & 0.39 & 0.14 & 0.32 & 0.43 & 0.06 & 0.26 & 0.42 & 0.04 \\
\hline EVO & 0.39 & 0.26 & 0.16 & 0.29 & 0.32 & 0.12 & 0.37 & 0.37 & 0.02 & 0.30 & 0.31 & 0.10 \\
\hline CRE & 0.34 & 0.24 & 0.12 & 0.30 & 0.38 & 0.21 & 0.29 & 0.44 & 0.20 & 0.30 & 0.38 & 0.13 \\
\hline GRA & 0.24 & 0.51 & 0.19 & 0.28 & 0.43 & 0.14 & 0.28 & 0.40 & 0.31 & 0.35 & 0.41 & 0.31 \\
\hline ORI & 0.23 & 0.38 & 0.35 & 0.32 & 0.39 & 0.28 & 0.37 & 0.44 & 0.08 & 0.33 & 0.36 & 0.13 \\
\hline ERD & 0.37 & 0.43 & 0.14 & 0.34 & 0.42 & 0.15 & 0.25 & 0.67 & 0.12 & 0.27 & 0.52 & 0.41 \\
\hline LAM & 0.27 & 0.15 & 0.02 & 0.29 & 0.36 & 0.08 & 0.35 & 0.38 & 0.01 & 0.33 & 0.32 & 0.05 \\
\hline LEC & 0.27 & 0.32 & 0.20 & 0.30 & 0.49 & 0.21 & 0.35 & 0.47 & 0.09 & 0.35 & 0.56 & 0.15 \\
\hline ZIO & 0.30 & 0.28 & 0.15 & 0.38 & 0.37 & 0.08 & 0.30 & 0.55 & 0.15 & 0.26 & 0.50 & 0.29 \\
\hline PAL & 0.24 & 0.47 & 0.26 & 0.30 & 0.46 & 0.24 & 0.33 & 0.46 & 0.12 & 0.23 & 0.44 & 0.19 \\
\hline ROM & 0.21 & 0.46 & 0.28 & 0.27 & 0.46 & 0.29 & 0.36 & 0.48 & 0.21 & 0.28 & 0.51 & 0.28 \\
\hline SED & 0.28 & 0.25 & 0.12 & 0.32 & 0.31 & 0.07 & 0.27 & 0.47 & 0.19 & 0.25 & 0.46 & 0.20 \\
\hline THE & 0.25 & 0.64 & 0.25 & 0.35 & 0.55 & 0.23 & 0.42 & 0.51 & 0.17 & 0.37 & 0.62 & 0.24 \\
\hline TUL & 0.24 & 0.58 & 0.24 & 0.23 & 0.53 & 0.26 & 0.33 & 0.49 & 0.10 & 0.21 & 0.41 & 0.25 \\
\hline VIL & 0.25 & 0.43 & 0.31 & 0.40 & 0.44 & 0.18 & 0.38 & 0.48 & 0.15 & 0.34 & 0.45 & 0.19 \\
\hline \multicolumn{13}{|c|}{ Middle East } \\
\hline BHR & 0.34 & 0.40 & 0.20 & 0.38 & 0.35 & 0.29 & 0.41 & 0.43 & 0.27 & 0.32 & 0.54 & 0.39 \\
\hline DHA & 0.33 & 0.40 & 0.17 & 0.40 & 0.32 & 0.02 & 0.46 & 0.45 & 0.10 & 0.29 & 0.57 & 0.17 \\
\hline DHD & 0.26 & 0.48 & 0.19 & 0.35 & 0.39 & 0.13 & 0.48 & 0.47 & 0.17 & 0.32 & 0.57 & 0.17 \\
\hline HMM & 0.27 & 0.42 & 0.20 & 0.33 & 0.32 & 0.06 & 0.48 & 0.35 & 0.08 & 0.31 & 0.53 & 0.05 \\
\hline MUS & 0.30 & 0.44 & 0.17 & 0.32 & 0.36 & 0.12 & 0.48 & 0.39 & 0.12 & 0.28 & 0.58 & 0.14 \\
\hline SVI & 0.29 & 0.31 & 0.09 & 0.38 & 0.25 & -0.08 & 0.34 & 0.42 & -0.08 & 0.26 & 0.52 & 0.01 \\
\hline
\end{tabular}


S. Basart et al.: Aerosol characterization in Northern Africa, Northeastern Atlantic, Mediterranean Basin and Middle Ea 273
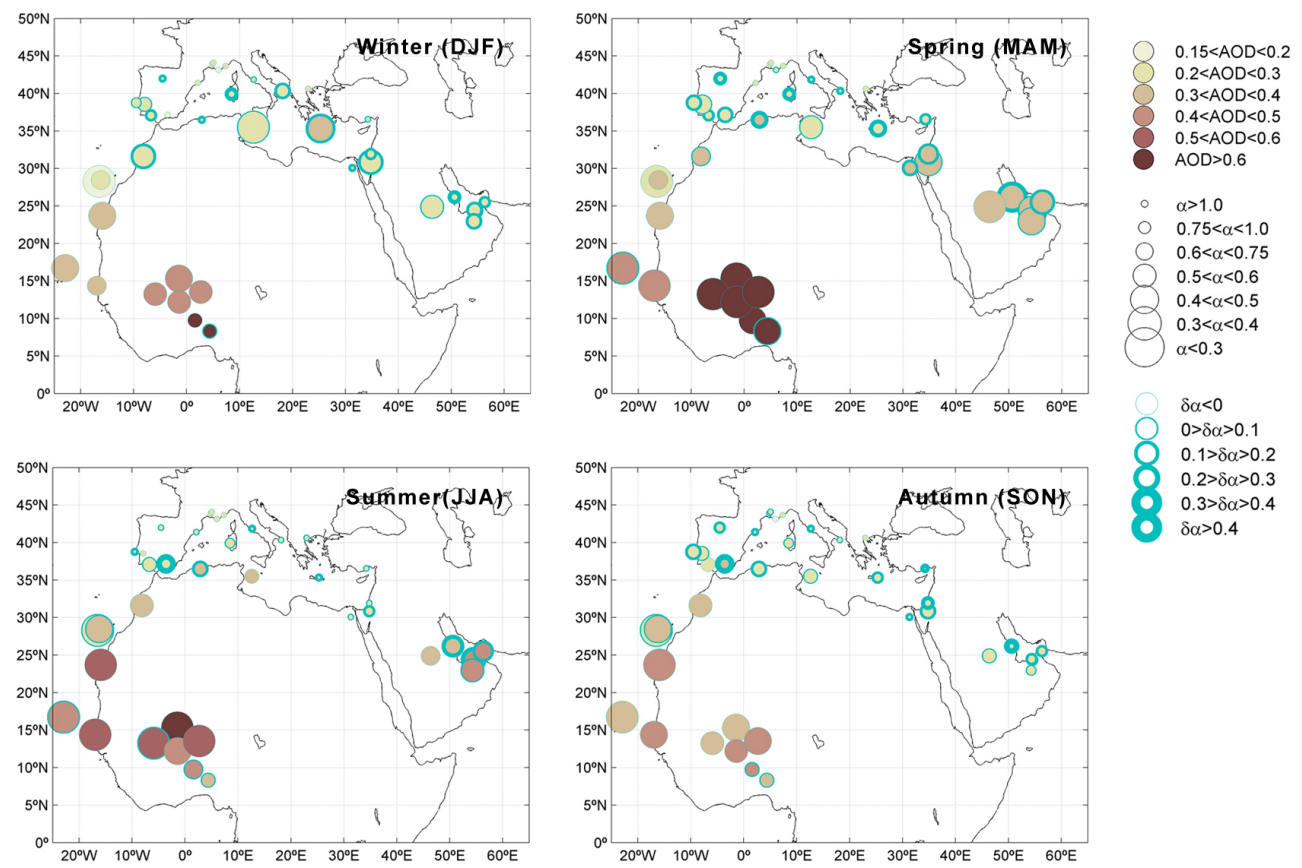

Fig. 6. Seasonal mean of measurements with AOD $>0.15$ for each AERONET station: the colour code indicates the seasonal mean of the AOD at $675 \mathrm{~nm}$, the size code is associated to the seasonal mean of the Ångström exponent calculated between 440 and $870 \mathrm{~nm}(\alpha)$ and the blue contourn code is associated to the seasonal mean of the Ångström exponent difference, $\delta \alpha=\alpha(440,675)-\alpha(675,870)$.
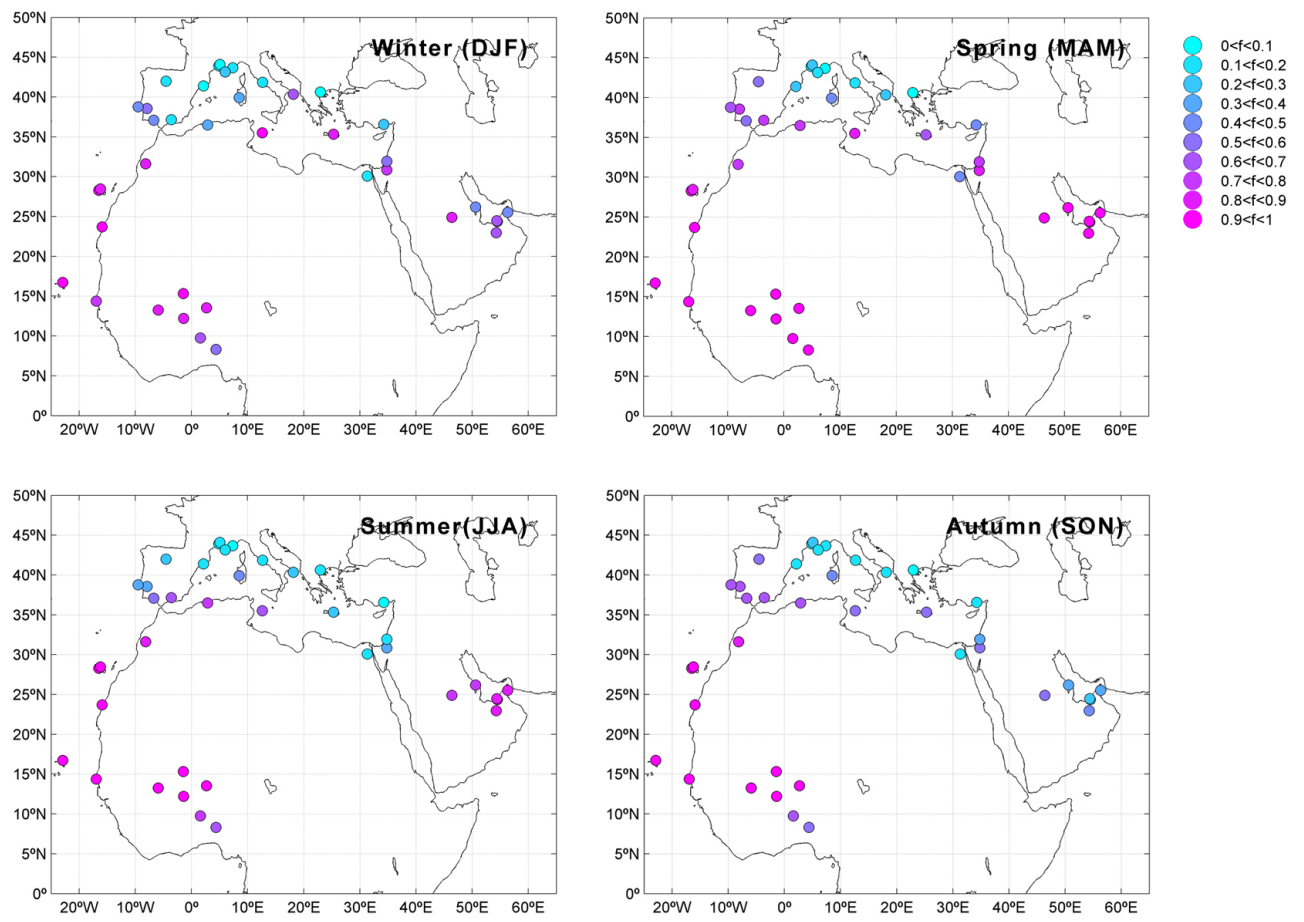

Fig. 7. Seasonal frequency of large aerosols (corresponding to particles with AOD $>0.15$ and $\alpha<0.75$ ) with respect to the total number of measurements with AOD $>0.15$ for each AERONET station, being 0 (blue) when no large aerosols are observed and 1 (pink) when all dataset is concentrated in this coarse fraction. 
As shown in Fig. 7, the proportion of large particles (AOD $>0.15$ and $\alpha<0.75)$ is high during the whole year $(>50 \%)$, especially in spring (when coarse aerosols represent more than $85 \%$ of the data) and summer. Dust transport downwind from source regions varies seasonally. This transport is driven by the latitudinal shift of the Intertropical Front which corresponds to the convergence zone between the northern winds, called the Harmattan, and the monsoon winds coming from the South. From late February to early May the Harmattan wind index is maximum (Sultan et al., 2005). Notice that DJO and ILO show the highest frequency of coarse fractions in spring (Fig. 7).

On the other hand, these stations clearly detected a second aerosol type (i.e. see ILO in Fig. 5) contributing to the turbidity (AOD up to 1.5 ) with high $\alpha$ values $(\sim 1.5)$ and negative $\delta \alpha(<-0.2)$ that corresponds to $\eta \sim 70 \%$ and $R_{f} \sim 0.13 \mu \mathrm{m}$. As shown in Fig. 6, ILO and DJO stations present larger contributions of fine aerosols (especially in late autumn-winter) than the rest of sites in this region. This is due to the wellknown presence of fine biomass burning aerosols originating from the sub-Sahel zone (Ogunjobi et al., 2008). The Savannah vegetation is characteristic of the Sudanian zone where fire activities are important during winter. During this season, the interaction of mineral dust and biomass burning aerosols is at its maximum over the region. Thus, all sites present a similar behaviour in the AdA space, associated to $R_{f}$ constant values $(\sim 0.15 \mu \mathrm{m})$ and $\eta$ variying between 40 and $70 \%$ (see BAN and ILO in Fig. 5). Furthermore, as shown in Fig. 6, all sites present the lowest AOD values in summer and autumn (coinciding with maximum rainfall and cloud cover). Particularly in ILO and DJO, we observe a decrease in $\alpha$ values and an increase of $\delta \alpha$ values $(\sim 0.10)$ which indicates the interaction of two separate particle modes. This is due to the presence of fine aerosols originating from anthropogenic activities along the Nigeria coast (Fig. 1).

At higher latitudes, DAH and SAA present relatively few measurements during winter, the period of maximum rainfall and cloud cover. They show an important coarse fraction during the whole year (Fig. 7) which is associated to large mineral particles with $\alpha<0.6$ and $\delta \alpha$ slightly negative that corresponds to $\eta<50 \%$ and AOD maxima $<2$ (Fig. 5). As shown in Fig. 7, maximum dust contributions are observed in summertime when the Intertropical Front is found in its northernmost position.

In addition to large mineral particles, SAA (Fig. 5) presents a small fraction of fine aerosols $(\alpha \sim 1.4$ and $\delta \alpha \sim-0.5)$ related to low AODs $(<0.2)$ which corresponds to $\eta \sim 70 \%$ and $R_{f} \sim 0.13 \mu \mathrm{m}$ associated to pollution aerosols from local and regional activities. Thus, SAA shows positive $\delta \alpha$ values (especially in winter) due to the presence of different aerosol modes (e.g. maritime, desert dust and fine pollution aerosols) except in summertime (Fig. 6) when enhanced Saharan dust activity and favourable transport conditions to this area occur (Middleton and Goudie, 2001).

\subsection{Eastern Tropical North Atlantic}

CVR is located approximately $600 \mathrm{~km} \mathrm{NW}$ of DAK, in the outflow of Saharan dust from West Africa. In spite of its coastal location CVR (Fig. 5) presents a similar behaviour to the continental station DAK, characterized by a large coarse fraction (Fig. 7) associated to $\eta<50 \%$ and AOD maxima $<3$. High aerosol loading from spring to autumn (Fig. 6), associated to low $\alpha$ values and high extinctions, indicates that mineral dust dominates the aerosol regime, due to frequent Saharan dust outbreaks. The situation is more complex in wintertime when the aerosol loading is lower. In this period, the contribution of sea salt and small particles is significant. As shown in Fig. 5, such fine particles conditions associated to a $\eta \sim 70 \%$ change to higher coarse fractions along $R_{f}$ constant curves $(\sim 0.15 \mu \mathrm{m})$. Chemical analysis from samples taken at ground level, and air mass trajectory analysis (Chiapello et al., 1999) explain such fine aerosols as sulfates transported from urban and industrial regions in Southern Europe and/or Northwestern Africa, and biomass burning from Savannah fires, as well as, the contributions of local anthropogenic sources.

\subsection{Eastern Sub-Tropical North Atlantic}

Roughly $100 \mathrm{~km}$ west of the Moroccan coast, in the Canary Islands, we find SCO (at sea level) and IZO (2370 $\mathrm{m}$ a.s.1.) sites. Quasi-permanent subsidence conditions in the free troposphere together with frequent trade winds flow in the lowest troposphere resulting in a strong and stable temperature inversion (located at $1400 \mathrm{~m}$ a.s.l. on average) that separates a dry free troposphere from a relatively fresh and humid oceanic boundary layer (Torres et al., 2002). The proximity to the Sahara desert and the regional atmospheric circulation exert a decisive influence on the dust climatology of this region (Viana et al., 2002; Querol et al., 2004; Alonso-Pérez et al., 2007). Although these sites are situated very close to each other, they present a very different behaviour (SCO is located at $\sim 50 \mathrm{~m}$ a.s.l. within the oceanic boundary layer, whereas IZO is located at $\sim 2370 \mathrm{~m}$ a.s.1, normally under free troposphere conditions).

Thus, the background conditions at IZO are associated to low AOD values ( $\sim 85 \%$ of its AOD values are under 0.15 , e.g. Table 1). As shown in Fig. 5, AODs above 0.15 are associated to large particles with $\alpha<0.25$ and $\delta \alpha \sim 0$ that correspond to $\eta<30 \%$ (Fig. 5), i.e. values similar to the ones observed at sub-Sahelian sites. In winter, AOD $>0.15$ represents $<1 \%$ of the recorded data while in summer AOD $>0.15$ represents $\sim 50 \%$ of them. This shows an enhancement of Saharan dust transport at this site during summer, in agreement with Prospero et al. (1995).

SCO is located in the city centre of Santa Cruz de Tenerife in the vicinity of the city harbour. This site presents a large coarse fraction associated to $\eta<70 \%$ and AOD maxima $<1.5$. High aerosol loading from spring to autumn 
(Fig. 6), associated to low $\alpha$ values and high extinctions, indicates that mineral dust dominates the aerosol regime, due to frequent Saharan dust outbreaks. The predominance of the trade winds (NE) in the oceanic boundary layer plays a key role in the atmospheric dynamics of this site. It favours the dispersion of pollutants from local urban and industrial activities over the ocean together with the occasional transport of European polluted air masses to this region (Viana et al., 2002). Consequently, the proportion of fine anthropogenic aerosols at SCO is lower than those in regions with similar urban and industrial development in continental environments (Rodríguez and Guerra, 2001; Rodríguez et al., 2008). In general, this fine fraction of pollution aerosols appears well-mixed with coarse mode aerosols like maritime particles $(\sim 50 \%$ of its $\mathrm{AOD}>0.15$ are associated to $\delta \alpha>0)$. Thus, as shown in Fig. 7, the coarse fraction of this urban site remains very high during all the year.

Long-range dust transport above the trade wind inversion layer at IZO is observed from early summer to early-autumn. Low level dust intrusions are detected at SCO mainly in winter (from January to March) and in autumn, in agreement with the previous studies in this North Atlantic region (e.g. Torres et al., 2002; Viana et al., 2002; Alonso-Pérez et al., 2007).

\subsection{Iberian peninsula}

At higher latitudes, we find the Iberian Peninsula. The origin of the air masses arriving to this region is driven by the Azores high pressure system which intensifies during the warm season inducing very weak pressure gradient conditions all over the region (Martin-Vide, 1984). This favours the development of local thermal circulations, such as coastal and mountain breezes. EVO, ROC, ARE, GRA and PAL sites in the Iberian Peninsula show a frequent background situation associated to low AOD values ( $~ 70 \%$ of its AOD values are lower than 0.15 , see Table 1$)$. High extinctions $(\mathrm{AOD}>1)$ are associated to large particles with $\alpha<0.6$ and $\delta \alpha \sim 0$ that correspond to $\eta<30 \%$ with a marked South-toNorth gradient with AODs maxima $<2$ in ARE (Fig. 5) and $<1$ in ROC and PAL. These large particles are linked to frequent African dust plumes affecting this area mainly in early-spring and summer (Rodríguez et al., 2001; AladosArboledas et al., 2003; Silva et al., 2003; Querol et al., 2004; Lyamani et al., 2005; Elias et al., 2006; Toledano et al., 2007; Wagner et al., 2009).

All these sites show a second cluster (see ARE in Fig. 5) associated to $\alpha>1.5$ and $\delta \alpha<-0.2$. These values correspond to $\eta \sim 80 \%$ and $R_{f} \sim 0.13 \mu \mathrm{m}$ related to polluted and continental air masses (Alados-Arboledas et al., 2003; Querol et al., 2004; Toledano et al., 2007). In fact, local pollution episodes (mainly in late autumn and winter) as well as emissions from Central and Eastern Europe (Querol et al., 2004) and sometimes as far as the Eastern Coast of North America (Alados-Arboledas et al., 2008) are potential sources of fine aerosol in this region. The one-mode fine aerosol $(\delta \alpha<0.1$ and $\alpha>1.2$ ) observed at ARE throughout the year are probably due to its proximity to a large industrial area (Toledano et al., 2007).

In summertime, under high isolation and low humidity conditions, fine biomass burning aerosols from fires in the Iberian Peninsula and Southern France (Belo, 2004; Elias et al., 2006) can be detected. AODs during these polluteion events $(0.15<\mathrm{AOD}<0.7)$ are lower than those recorded during African dust outbreaks but clearly higher than those observed during background Atlantic advection conditions. This fine particle cluster grows following the constant $R_{f}$ curves $(\sim 0.13 \mu \mathrm{m})$ due to the presence of coarse particle (likely maritime aerosols). Additionally, in winter (under stagnant conditions), a growth of AOD along constant $\eta$ lines ( $\sim 85 \%$ ), linked to both coagulation-aging and hydration, is observed.

Although African dust outbreaks over the Iberian Peninsula can occur throughout the year, its contribution to AOD is more important in spring (Fig. 7). In this season, coarse cluster normally appears well-mixed with other types of small particles as indicated by positive $\delta \alpha$ values $(\sim 0.20)$. Additionally, it is remarkable the seasonal differences (Fig. 6) between the sites located in south-western part of the Peninsula (ARE, ROC and EVO) and south-eastern (GRA) indicating different transport patterns in both areas.

\subsection{Mediterranean basin}

The Mediterranean basin is characterized by cold winters and hot summers. The stable anticyclonic weather conditions permits continuous measurements over long periods, especially in summer.

\subsubsection{Western Mediterranean}

The stations located in the Northwestern Mediterranean coast are close to numerous industrial and urban sources of primary pollutants. AVI (Fig. 5), TUL, CAR, VIL and BCN sites present an important fine particle cluster in the AdA space $(\alpha>1.6$ and $\delta \alpha<-0.3)$ associated to $\eta \sim 80 \%$ and $R_{f} \sim 0.12 \mu \mathrm{m}$. In fact, over $70 \%$ of their datasets are associated to this fine particle cluster (Fig. 7) which correspond to moderate extinctions (AOD $<0.7)$. AOD growth is linked to both coagulation-aging and hydration increase of $R_{f}$. At the same time coarse particles, likely maritime aerosols, superimpose their signal onto this fine mode. As shown in Fig. 5, a concurrent increase in AOD and coarse mode fraction along the $R_{f}$ curves $(\sim 0.12 \mu \mathrm{m})$ is observed. Conversely, highest extinctions (AOD maxima $>1$ ) are related to large particles $(\alpha<0.7)$ that corresponds to $\eta<40 \%$. This coarse particle cluster is associated to large dust aerosols from North African deserts. As shown in Table 2, coarse fraction exhibits positive $\delta \alpha$ values throughout the year which indicates the presence of small particles mixed with this coarse mode. 
The Northwestern Mediterranean coast is characterized by a high frequency of sea breeze conditions, which are intensified by topography. Under weak pressure gradients, coastal and nearby mountain breeze regime predominates favouring the development of polluted atmospheric layers at several heights (Pérez et al., 2004; Jimenez et al., 2006). Thus, Saharan dust is found at high altitudes, while fine pollution aerosols are concentrated at lower altitudes (e.g. Pérez et al., 2004). By late summer-early autumn, North African highs, located at surface level, and Atlantic depressions west of Portugal, favour air mass transport at low levels from the Western Sahara, Mauritania and the Sahel to the Northwestern Mediterranean (Moulin et al., 1998; Rodríguez et al., 2001; Escudero et al., 2005). These meteorological conditions are typically associated to the presence of rain resulting in the well-known "red rains" (Ávila et al., 1998). Thus, most of the Saharan intrusions during these rainy periods have not been recorded into our dataset because AERONET instruments do not operate during rain events.

\subsubsection{Central Mediterranean}

At southern latitudes, ORI, on the west coast of Sardinia, and BLI, in the Algerian coast, exhibit high extinctions $(\mathrm{AOD}>0.7)$ in the coarse fraction. This is caused by frequent North African dust advections. Both sites (included in Fig. 5) present highest extinctions (AOD $>1$ ) in the coarse mode $(\alpha<0.4$ and $\delta \alpha \sim 0)$ that corresponds to $\eta<30 \%$. Additionally to this coarse cluster, we detect in the AdA space a small fraction of fine aerosols ( $\alpha \sim 1.6$ and $\delta \alpha \sim-0.5)$ possibly from local anthropogenic sources and European pollution which is most important at the ORI site. This fine cluster is related to low extinctions $(\mathrm{AOD}<0.3)$ and $\eta>70 \%$. A simultaneous growth of AOD and coarse fraction (indicated by a decrease of $\alpha$ ) along constant $R_{f}$ curves is associated to cloud contamination or to the presence of coarse particles (maritime and dust aerosols). At the same time, coarse particles (likely dust) superimpose their signal onto this fine mode particles.

As shown in Fig. 7, the coarse fraction is most important in BLI than ORI during all year due to its proximity to African sources. Maxima contributions in spring and summer and minima in winter are observed, coinciding with the maximum and minimum incidence of Saharan dust transport, respectively, in this part of the Mediterranean basin (Barnaba and Gobbi, 2004). Note the similarities in Figs. 6 and 7 between BLI and GRA (in the Iberian Peninsula) indicating common African dust sources and pathways at both locations.

At about $130 \mathrm{~km}$ east of the Tunisian coast, LAM (Fig. 5) shows an important cluster in the coarse mode in the AdA space $(\alpha<0.5$ and $\delta \alpha \sim 0)$ associated to frequent Saharan dust outbreaks to this site (Pace et al., 2006) that corresponds to $\eta<50 \%$. This coarse contribution is high throughout the year (Fig. 7) and high extinctions (AOD $>1$ and ranging up to 2.5) are related to almost pure desert dust $(\eta<30 \%, \alpha<0.3$ and $\delta \alpha \sim 0)$ as observed in Sub-Sahelian sites. Moreover, a second aerosol type (Fig. 5) with AOD $<0.4$ and $\alpha \sim 1.8$ that corresponds to $\eta \sim 90 \%$ and $R_{f} \sim 0.14 \mu \mathrm{m}$ is observed. A growth of AOD and coarse fraction is found along the constant $R_{f}$ curves due to the presence of coarse particles. In summertime, when wet removal is practically absent and photochemical reactions are favoured, the contribution of small pollution particles is maximum (Fig. 7). They are related to longrange transport of urban and industrial aerosols from Western, Central and Eastern Europe as well as from biomass burning (Pace et al., 2006). In winter, AOD $>0.15$ represents $<7 \%$ of data and it is associated to dust events (Figs. 6 and $7)$. In this season, the high contribution of aerosols associated to lower AOD values $(<0.15)$ indicates contribution of maritime aerosols and a minimum incidence of long range transport.

Further north, in the Italian Peninsula, ROM (Fig. 5) and LEC sites show an important fine cluster in the AdA space ( $\alpha>1.8$ and $\delta \alpha \sim-0.4)$ that corresponds to $\eta \sim 80 \%$ and $R_{f} \sim 0.12 \mu \mathrm{m}$. The fine mode at ROM is mainly due to secondary particles of local origin, and long range transport is a minor component (Gobbi et al., 2004). On the contrary, LEC presents a more important contribution of fine pollution aerosols transported from Central and Eastern Europe (Lelieveld et al., 2002), and from the Atlantic Ocean (De Tomasi and Perrone, 2003). LEC is also affected by fine particles originated by frequent summertime forest fires (Perrone et al., 2005). At both sites, a simultaneous growth of AOD and coarse fraction (indicated by a decrease of $\alpha$ ) along constant $R_{f}$ curves in the AdA space is associated to the presence of coarse particles (likely dust). In addition, in ROM (Fig. 5), the extension of fine pollution particles to higher AOD occurs perpendicularly to the black line due to the presence of these large particles. Additionally, both sites, are impacted by Saharan dust with AOD $>0.4$ (with AOD maxima of 1.5 ) and $\alpha<0.75$ that corresponds to $\eta<30 \%$. This coarse cluster is more important at LEC than at ROM (Fig. 7) and it usually appears well-mixed with other small particles (Table 2). Thus, ROM and LEC present different seasonal features (Fig. 6). The high contribution of large size aerosols at LEC in winter (Figs. 6 and 7) is due to the lower contribution of long-range transported fine particles and a higher weather instability that does not favour the accumulation of fine particles. From spring to autumn, a decrease of $\alpha$ values (Fig. 6) is associated to an increase of the frequency of long-range transport of Saharan dust to southern and central Italy (Barnaba and Gobbi, 2004, Gobbi et al., 2004; Mona et al., 2006).

\subsubsection{Eastern Mediterranean}

In the Central-Eastern Mediterranean large particles are quasi inexistent at THE (Fig. 7). This site is characterized by rather heavy pollution being strongly influenced by regional 
(Central and Eastern Europe) and local urban and industrial sources as well as by biomass burning that may also contribute sporadically from areas at the northern coast of the Black Sea (Gerasopoulos et al., 2003; Kazadzis et al., 2007). As shown in Fig. 5, high extinctions (AOD $>0.7)$ mainly cluster in the fine mode $(\alpha \sim 1.8$ and $\delta \alpha \sim-0.3)$ that corresponds to $\eta \sim 85 \%$ and $R_{f} \sim 0.13 \mu \mathrm{m}$. This fine polluted cluster presents a growing AOD linked to both coagulation-aging (along constant $\eta \sim 85 \%$ ) and hydration-type increase along constant $R_{f}$ curves. Occasional events of long-range transport of desert dust are observed only in summer (Fig. 7) and commonly appear mixed with fine pollution aerosols (Fig. 5). These desert dust events are associated to AODs between 0.7 and 1 as also suggested by Balis et al. (2006).

In the Eastern Mediterranean, CRE, ERD, ZIO (Fig. 5), SED and CAI sites present high extinctions (AOD $>1$ ) associated to clustering in the coarse mode $(\alpha<0.75)$ in the AdA space. They are related to large mineral aerosols originated in desert dust source regions such as Anatolian plateau, Saharan and Negev deserts (Andreae et al., 2002; Kubilay et al., 2003; Derimian et al., 2006) corresponding to $\eta<40 \%$. As shown in Fig. 7, maximum contribution of the coarse particles, associated to high extinctions, is observed in spring in this area. During this season, long-range Saharan dust transport and uplifted dust particles from surrounding deserts are very important (Kubilay et al., 2000; Kubilay et al., 2003; Barnaba and Gobbi, 2004).

The aerosol climatology of CRE site is strongly determined by the maritime environment with high concentrations of sea-salt aerosols ( $>65 \%$ of its AOD is $<0.15$ ) which constitute the background conditions. The CRE data shows high AOD ( $>0.7)$, mainly clustering in the coarse mode $(\alpha<0.6$ and $\delta \alpha \sim 0)$ that corresponds to $\eta<30 \%$. These large particles are related to long-range transport from Sahara, and, to a minor degree, from source regions in the eastern part of Mediterranean basin (such as Anatolian plateau, Saharan and Negev deserts) and Middle East (Dayan et al., 1991; Kubilay et al., 2000; Barnaba and Gobbi, 2004; Fotiadi et al., 2006). As shown in Figs. 6 and 7, maxima contributions of this coarse mode are observed in winter and spring. In winter, AOD $>0.15$ represents $<20 \%$ of data and it is associated to dust events (Figs. 6 and 7). In this season, high contribution of aerosols associated to lower AOD values $(<0.15)$ is a consequence of the background situation dominated by the presence of maritime aerosols (Fotiadi et al., 2006; Kalivitis et al., 2007; Gerasopoulos et al., 2007). In spring, a decrease of $\delta \alpha$ values $(\sim 0)$ in the coarse mode with respect to the rest of the year (Table 2) indicates an increase of longrange dust transport to this area. Contributions from urbanindustrial aerosol intrusions into the region from the Eastern Europe, Balkan area, and Anatolia are maxima in summer (Figs. 6 and 7). This fine mode $(\alpha>1.5$ and $\delta \alpha \sim-0.2)$ is associated to low AODs $(<0.4)$ and corresponds to $\eta>70 \%$. The growth to higher AODs and coarse fractions occurs perpendicularly to the constant $R_{f}$ line due to the coexistence of coarse aerosols (likely maritime) and small pollution particles. Therefore, it is a common situation that they appear well-mixed as indicated by positives values of $\delta \alpha$ throughout the year (Fig. 6).

A second cluster in the fine mode region $(\alpha \sim 1.6$ and $\delta \alpha \sim-0.3$ ), that corresponds to $\eta \sim 70 \%$ and $R_{f} \sim 0.14 \mu \mathrm{m}$, is observed. This fine mode is associated to pollution particles and it is especially remarkable at coastal sites of Turkey and Israel such as ERD and ZIO (Fig. 7), where the urbanindustrial local emissions are significant. Most of the longrange transported aerosol in this region is attributed to Central and Eastern Europe, especially along the Israeli coast (Sciare et al., 2003; Fotiadi et al., 2006), as well as to Southern Russia (Andreae et al., 2002; Derimian et al., 2006) with additional contributions from marine biogenic activities and forest fires in the region. This fine cluster presents an increase in AOD and coarse mode fraction along the constants $R_{f}$ curves (see ZIO in Fig. 5). Moreover, the growth to higher AODs also occurs perpendicularly to the constant $R_{f}$ line (see ZIO in Fig. 5). This is due to the coexistence of mineral dust and fine pollution aerosols. Additionally, in highpollution locations (such as ZIO and ERD), branching of data along $\eta$ lines is observed which is associated to coagulationaging growth. The contribution of small pollution particles is maximum in summer (Fig. 7), when wet removal is practically absent and the accumulation of pollution is favoured.

\subsection{Middle East}

The sites located in the Arabian Peninsula (MUS, DHA, DHD, BHR, HMM and SVI) provide a relatively large amount of measurements thanks to stable weather conditions in this region. The United Arab Emirates and the Persian Gulf include strong regional desert dust sources of predominately coarse mode-size particles, as well as important fine mode pollution particle sources from petroleum extraction and processing facilities which are located on islands, seaplatforms and coastal regions of the Persian Gulf. Thus, as shown in Fig. 6, the coastal sites in the northeastern part of the United Arab Emirates such as MUS, DHA and DHD, as well as BHR in the Persian Gulf, attain positive $\delta \alpha$ values during almost all year $(\sim 0.2)$ which indicate the coexistence of two particle modes.

For the coastal sites of MUS (Fig. 5), DHA, DHD and BHR, we observe desert dust with AOD maxima of 1.5 , $\alpha<0.75$ and $\delta \alpha \geq 0$ that corresponds to $\eta<40 \%$. As opposite, small particles from petroleum industry emissions are associated to fine mode $(\alpha \sim 1.6$ and $\delta \alpha \sim-0.2)$ and AOD $<0.7$ corresponding to $\eta>70 \%$ and $R_{f} \sim 0.13 \mu \mathrm{m}$. The interaction of mineral dust and pollution is strong at these coastal sites. In the AdA space, this mixed region follows $R_{f}$ constant curves and is associated to $\eta$ between 40 and $70 \%$ (see MUS in Fig. 5). Additionally, and due to the proximity of these stations to the sea, an increase in AOD is linked to both coagulation-aging and hygroscopic-type increase in $R_{f}$. 
Conversely, at the inland desert sites, as HMM (Fig. 5) and SVI, desert dust is the main aerosol constituent, being associated with high AOD $(>0.7$ ranging up $>2)$ mainly clustering in the coarse mode $(\alpha<0.75$ and $\delta \alpha$ variable). This cluster corresponds to $\eta<50 \%$. HMM $(\sim 125 \mathrm{~km}$ inland from the Gulf; Fig. 5) shows a contribution of small particles from industrial emissions that corresponds to $\eta \sim 80 \%$ and $R_{f} \sim 0.13 \mu \mathrm{m}$. This transport is consequence of regional sea and land breeze circulations in this area (Eck et al., 2008) which produce occasional increases of fine mode particles from offshore petroleum operations. This fine mode presents a growth of AOD and coarse mode fraction along the constants $R_{f}$ curves. Otherwise, SVI is located in the middle of the Arabian Peninsula, near to At Riyad (the capital of Saudi Arabia and its largest city) and far away from the Persian Gulf or other industrialized areas. SVI presents its highest extinctions $(\mathrm{AOD}>1)$ in the coarse mode region $(\alpha<0.75$ and $\delta \alpha<0.1)$ which presents an expanded particle size range suggesting significant variations in the particle size-distribution. It ranges from almost pure coarsemode dust particles (associated to $\alpha<0.3$ and $\eta<30 \%$ ) to a mixture of coarse particles and fine-mode pollution aerosols $(\eta<70 \%)$ caused by anthropogenic activities in the region (Kaskaoutis et al., 2007).

As shown in Fig. 7, the contribution of large particles is maximum in spring and summer. In spring, all sites present similar AODs and $\alpha$ values (Fig. 6). It is associated to maximum desert dust local activity (Smirnov et al., 2002b; Eck et al., 2005; Kim et al., 2007; Kaskaoutis et al., 2007). On the contrary, in summer, MUS, DHA, DHD and HMM show higher AODs than BHR and SVI coinciding with a general increase of $\alpha$ values (Fig. 6). In this season, the southwest monsoon introduces a northwesterly flow over the Arabian Peninsula bringing extremely dry and dust-loaded air from the Iraq and Southern Iran deserts (Liu et al., 2000). In addition to long range transport, regional sea-land breeze circulations cause both, a regional transport of polluted and humid air masses from Persian Gulf to inland regions, and a dust transport from these regions towards the coast and the Gulf (Eck et al., 2008) favouring a mixing of desert dust and fine pollution aerosols.

\section{Summary and conclusions}

In the present work, we have provided an aerosol characterization (mainly focusing on the contribution of mineral particles) based on direct-sun observations of 39 AERONET stations which include at least an annual cycle within the 19942007 period. These stations are located in the region most affected by the presence of Saharan and Arabian desert dust: Northern Africa, Northeastern Atlantic, Mediterranean Basin and Middle East. In addition to large mineral particles, fine pollution aerosols, originated in industrialized countries surrounding the Mediterranean Sea and in the Persian Gulf, and biomass burning aerosols, produced in the Sahel and Southern European countries, are expected to dominate the atmospheric aerosol load in this region.

The method used to discriminate different aerosol types, introduced in Gobbi et al. (2007), relies on the combined analysis of the Ångström exponent $(\alpha)$ and its spectral curvature, here represented by $\delta \alpha=\alpha(440,675)-\alpha(675,870)$. Plotting data in these coordinates was shown to allow for inference of aerosol fine mode size $\left(R_{f}\right)$ and fractional contribution $(\eta)$ to total AOD by means of reference points. It is also possible to separate the AOD increase due to finemode aerosol humidification and/or coagulation, from AOD growth due to the increase in coarse particles concentrations or cloud contamination.

In areas around the Sahara desert, mineral dust is found to be the main aerosol constituent, being associated with coarse mode particles corresponding to $\eta<40 \%$. Highest extinctions (AOD $>4$ ) are related to $\eta<30 \%$ and $R_{f} \sim 0.3 \mu \mathrm{m}$ that we assumed as typical of pure Saharan dust particles. Superimposed to this coarse cluster, small particles associated to fine mode ( $\alpha>1.5$ and $\delta \alpha \sim-0.3$ ), that corresponds to $\eta \sim 70 \%$ and $R_{f} \sim 0.13 \mu \mathrm{m}$, are also observed. In southern sites, in the Sahel region, this fine contribution is limited to winter and it is originated by biomass burning, meanwhile, at northern latitudes, the fine cluster is most important and is linked to the local or regional urban-industrial emissions. Frequently, the interaction of large mineral particles and small aerosols results in well-mixed particles associated to $\delta \alpha>0$. Eastern Tropical and sub-Tropical North Atlantic sites located in the outflow of Saharan dust from West Africa present similar behaviour to the continental stations located at the same latitudes, characterized by a large mineral dust fraction from spring to autumn.

In spite of the Iberian Peninsula sites showing frequent background conditions associated to low AOD values $(<0.15)$, high extinctions $(\mathrm{AOD}>1)$ are associated to large particles with $\alpha<0.6$ and $\delta \alpha \sim 0$ that correspond to $\eta<30 \%$, with a marked South-to-North gradient. This is linked to frequent African dust plumes affecting this area mainly in early-spring and summer. Additionally, a second cluster associated to $\alpha>1.5$ and $\delta \alpha<-0.2$ that correspond to $\eta \sim 80 \%$ and $R_{f} \sim 0.13 \mu \mathrm{m}$ can be related to polluted European continental air masses.

The highest polluted sites in the Central-Eastern Mediterranean show measurements clustering in the fine mode $(\alpha>1.5$ and $\delta \alpha \sim-0.3)$ that corresponds to $\eta>70 \%$ and $R_{f} \sim 0.13 \mu \mathrm{m}$. In this case, the AOD increase is linked to both coagulation-aging and hydration type increase in $R_{f}$. Furthermore, a North-to-South AOD gradient, related to coarse mode ( $\alpha<0.75$ and $\delta \alpha$ variable), that corresponds to $\eta<40 \%$, is associated to seasonal dust export. In general, the maximum dust activity appears in spring and summer over the whole Mediterranean Basin. In wintertime, the high contribution of aerosols associated to lower AOD values $(<0.15)$ indicates significant contributions from maritime aerosols 
compared to dust. However, some few dust outbreaks can also take place in this season. In general, desert dust appears well-mixed with other types of particles like fine pollution aerosols. They are associated to $\mathrm{AOD}<1$, but in some intense Saharan outbreaks (with $\delta \alpha \sim 0$ ) can reach AOD values of 2. The long-range transport of these dust particles usually occurs at higher altitudes (above $1500 \mathrm{~m}$ a.s.l), whereas, urban-industrial and maritime aerosols concentrate at lower altitudes.

In the Middle East, all sites show high extinctions (AOD up to 3) mainly clustering in the coarse mode, that corresponds to $\eta<50 \%$. These extinctions are lower than those observed at the African sites. In coastal sites of the Persian Gulf, fine-mode aerosols ( $\alpha>1.6$ and $\delta \alpha \sim-0.3)$ largely produced by the oil industry, are observed. They are associated to $\eta>70 \%$ and $R_{f} \sim 0.13 \mu \mathrm{m}$. The AOD increase is linked to both coagulation-aging and hydration-type increase in $R_{f}$ due to very humid conditions in the Gulf. This variability of atmospheric particles type in conjunction with highly variable regional meteorology, results in a high variety of conditions in this region: some days are dominated by large particle desert dust, while others by fine pollution particles. However most of the days are characterized by a mixture of these two aerosol types.

Finally, this study confirms the robustness of the method of Gobbi et al. (2007) based on direct-sun measurements (more frequent and accurate than sky measurements) to track and characterize mixtures of pollution aerosol and mineral dust. We have also found that in the dataset we analysed $\delta \alpha<0$ values can be related to a dominant single mode fraction, independently whether it corresponds to fine (high $\alpha$ ) or to coarse (low $\alpha$ ) aerosols.

Acknowledgements. This work is the first step of a long way to walk. We wish to acknowledge the AERONET and PHOTONS networks, and the research groups that contribute to them who kindly provided their data. This work was funded by the project CICYT CGL2006-11879 of the Spanish Ministry of Education and Science. GPG activity was partly supported by the AEROCLOUDS project, funded by the Italian Research Ministry.

Edited by: Y. Balkanski

\section{References}

Alados-Arboledas, L., Lyamani, H. and Olmo, F. J.: Aerosol size properties at Armilla, Granada (Spain), Q. J. Roy. Meteor. Soc., 129(590), 1395-1413, 2003.

Alados-Arboledas, L., Alcantara, A., Olmo, F. J., Martinez-Lozano, J. A., Estelles, V., Cachorro, V., Silva, A. M., Horvath, H., Gangl, M., and Diaz, A.: Aerosol columnar properties retrieved from CIMEL radiometers during VELETA 2002, Atmos. Environ., 42(11), 2654-2667, 2008.

Alonso-Pérez, S., Cuevas, E., Querol, X., Viana, M., and Guerra, J. C.: Impact of the Saharan dust outbreaks on the ambient levels of total suspended particles (TSP) in the marine boundary layer
(MBL) of the Subtropical Eastern North Atlantic Ocean, Atmos. Environ., 41(40), 9468-9480, 2007.

Andreae, T. W., Andreae, M. O., Ichoku, C., Maenhaut, W., Cafmeyer, J., Karnieli, A. and Orlovsky, L.: Light scattering by dust and anthropogenic aerosol at a remote site in the Negev desert, Israel, J. Geophys. Res., 107(D2), 4008, doi:10.1029/2001JD900252, 2002.

Ångström, A.: On the Atmospheric Transmission of Sun Radiation and on Dust in the Air, Geografiska Annaler, 11, 156-166, 1929.

Ávila, A., M. Alarcón and I. Queralt: The chemical composition of dust transported in red rains- Its contribution to the biogeochemical cycle of a holm oak forest in Catalonia (Spain), Atmos. Environ., 32(2), 179-191, 1998.

Balis, D., Amiridis, V., Kazadzis, S., Papayannis, A., Tsaknakis, G., Tzortzakis, S., Kalivitis, N., Vrekoussis, M., Kanakidou, M., Mihalopoulos, N., Chourdakis, G., Nickovic, S., Perez, C., Baldasano, J. M., and Drakakis, M.: Optical characteristics of desert dust over the East Mediterranean during summer: a case study, Ann. Geophys., 24, 807-821, 2006, http://www.ann-geophys.net/24/807/2006/.

Barnaba, F. and Gobbi, G. P.: Aerosol seasonal variability over the Mediterranean region and relative impact of maritime, continental and Saharan dust particles over the basin from MODIS data in the year 2001, Atmos. Chem. Phys., 4, 2367-2391, 2004, http://www.atmos-chem-phys.net/4/2367/2004/.

Belo, N.: Caracterização das propiedades ópitcas dos aerossóis à superfície na região de Évora. Departamento de Física, Universidade de Lisboa, Lisboa, 2004.

Chandra, S., Satheesh, S. K. and Srinivasan, J.: Can the state of mixing of black carbon aerosols explain the mystery of 'excess' atmospheric absorption?, J. Geophys. Res. Lett., 31, L19109, doi:10.1029/2004GL020662, 2004.

Chiapello, I., Bergametti, G., Chatenet, B., Dulac, F., Jankowiak, I., Liousse, C., and Santos Soares, E.: Contribution of the different aerosol species to the aerosol mass load and optical depth over the northeastern tropical Atlantic, J. Geophys. Res., 104(D4), 4025-4035, 1999.

Dayan, U., Heffter, J., Miller, J., and Gutman, G.: Dust Intrusion Events into the Mediterranean Basin, Appl. Meteorol., 30(8), 1185-1199, 1991.

De Tomasi, F. and Perrone, M. R.: Lidar measurements of tropospheric water vapor and aerosol profiles over southeastern Italy, J. Geophys. Res., 108, 4286-4297, 2003.

Derimian, Y., Karnieli, A., Kaufman, Y. J., Andreae, M. O., Andreae, T. W., Dubovik, O., Maenhaut, W., Koren, I. and Holben, B. N.: Dust and pollution aerosols over the Negev desert, Israel: Properties, transport, and radiative effect, J. Geophys. Res., 111, D05205, doi:10.1029/2005JD006549, 2006.

Dubovik, O. and King, M. D.: A flexible inversion algorithm for retrieval of aerosol optical properties from sun and sky radiance measurements, J. Geophys. Res., 105(D16), 20676 , doi:10.1029/2000JD900282, 2000.

Dubovik, O., Smirnov, A., Holben, B. N., King, M. D., Kaufman, Y. J., Eck, T. F., and Slutsker, I.: Accuracy assessments of aerosol optical properties retrieved from Aerosol Robotic Network (AERONET) Sun and sky radiance measurements, J. Geophys. Res., 105(D8), 9791-9806, 2000.

Dubovik, O., Holben, B. N., Eck, T. F., Smirnov, A., Kaufman, Y. J., King, M. D., Tanré, D., and Slutsker, I.: Variability of Ab- 
sorption and Optical Properties of Key Aerosol Types Observed in Worldwide Locations, Atmos. Sci., 59, 590-608, 2002.

Eck , T. F., Holben, B. N., Reid, J. S., Dubovik, O., Smirnov, A., O'Neill, N. T., Slutsker, I., and Kinne, S.: Wavelength dependence of optical depth of biomass burning, urban and desert dust aerosols, J. Geophys. Res., 104(D24), 31333-31350, 1999.

Eck, T. F., Holben, B. N., Dubovik, O., Smirnov, A., Goloub, P., Chen, H. B., Chatenet, B., Gomes, L., Zhang, X. Y., and Tsay, S. C.: Columnar aerosol optical properties at AERONET sites in central eastern Asia and aerosol transport to the tropical mid-Pacific, J. Geophys. Res, 110, D06202, doi:10.1029/2004JD005274, 2005.

Eck, T. F., Holben, B. N., Reid, J. S., Sinyuk, A., Dubovik, O., Smirnov, A., Giles, D., O’Neill, N. T., Tsay, S. C., and Ji, Q.: Spatial and temporal variability of column-integrated aerosol optical properties in the southern Arabian Gulf and United Arab Emirates in summer, J. Geophys. Res, 113, doi:10.1029/2007JD008944, 2008.

Elias, T., Silva, A. M., Belo, N., Pereira, S., Formenti, P., Helas, G., and Wagner, F.: Aerosol extinction in a remote continental region of the Iberian Peninsula during summer, J. Geophys. Res., 111(D14), D14204, doi:10.1029/2005JD006610, 2006.

Escudero, M., Castillo, S., Querol, X., Avila, A., Alarcón, M., Viana, M. M., Alastuey, A., Cuevas, E., and Rodríguez, S.: Wet and dry African dust episodes over Eastern Spain, J. Geophys. Res., 110, 4731-4746, 2005.

Fotiadi, A., Drakakis, E., Hatzianastassiou, N., Matsoukas, C., Pavlakis, K. G., Hatzidimitriou, D., Gerasopoulos, E., Mihalopoulos, N., and Vardavas, I.: Aerosol physical and optical properties in the Eastern Mediterranean Basin, Crete, from Aerosol Robotic Network Data, Atmos. Chem. Phys., 6, 77917834, 2006, http://www.atmos-chem-phys.net/6/7791/2006/.

Gerasopoulos, E., Andreae, M. O., Zerefos, C. S., Andreae, T. W., Balis, D., Formenti, P., Merlet, P., Amiridis, V., and Papastefanou, C.: Climatological aspects of aerosol optical properties in Northern Greece, Atmos. Chem. Phys., 3, 2059-2099, 2003, http://www.atmos-chem-phys.net/3/2059/2003/.

Gerasopoulos, E., Koulouri, E., Kalivitis, N., Kouvarakis, G., Saarikoski, S., Mäkelä, T., Hillamo, R., and Mihalopoulos, N.: Size-segregated mass distributions of aerosols over Eastern Mediterranean: seasonal variability and comparison with AERONET columnar size-distributions, Atmos. Chem. Phys., 7, 2551-2561, 2007,

http://www.atmos-chem-phys.net/7/2551/2007/.

Gobbi, G. P., Barnaba, F., and Ammannato, L.: The vertical distribution of aerosols, Saharan dust and cirrus clouds in Rome (Italy) in the year 2001, Atmos. Chem. Phys., 4, 351-359, 2004,

http://www.atmos-chem-phys.net/4/351/2004/.

Gobbi, G. P., Kaufman, Y. J., Koren, I., and Eck, T. F.: Classification of aerosol properties derived from AERONET direct sun data, Atmos. Chem. Phys., 7(2), 453-458, 2007.

Holben, B. N., Eck, T. F., Slutsker, I., Tanré, D., Buis, J. P., Setzer, A., Vermote, E., Reagan, J., Kaufman, Y., Nakajima, T., Lavenu, F., Jankowiak, I., and Smirnov, A.: AERONET: A Federated Instrument Network and Data Archive for Aerosol Characterization, Rem. Sens. Environ., 66, 1-16, 1998.

Holben, B. N., Tanre, D., Smirnov, A., Eck, T. F., Slutsker, I., Abuhassan, N., Newcomb, W. W., Schafer, J., Chatenet, B., Lavenue, F., Kaufman, Y. J., Castle, J. V., Setzer, A., Markham, B.,
Clark, D., Frouin, R., Halthore, R., Karnieli, A., O’Neill, N. T., Pietras, C., Pinker, R. T., Voss, K., and Zibordi, G.: An emerging ground-based aerosol climatology: Aerosol Optical Depth from AERONET, Geophys. Res., 106(12), 12067-12097, 2001.

IPCC, Intergovernmental Panel on Climate Change: Climate change 2001: Aerosols, their direct and indirect effects, Cambridge Univ. Press, New York, USA, 2001.

IPCC, Intergovernmental Panel on Climate Change: Climate change 2007: Synthesis Report, http://www.ipcc.ch/pdf/ assessment-report/ar4/syr/ar4_syr.pdf, 2007.

Jiménez, P., Jorba, O., Parra, R., and Baldasano, J. M.: Evaluation of MM5-EMICAT2000-CMAQ performance and sensitivity in complex terrain: High-resolution application to the northeastern Iberian Peninsula, Atmos. Environ., 40(26), 5056-5072, 2006.

Kalivitis, N., Gerasopoulos, E., Vrekoussis, M., Kouvarakis, G., Kubilay, N., Hatzianastassiou, N., Vardavas, I., and Mihalopoulos, N.: Dust transport over the eastern Mediterranean derived from Total Ozone Mapping Spectrometer, Aerosol Robotic Network, and surface measurements, J. Geophys. Res, 112, D03202, doi:10.1029/2006JD007510, 2007.

Kaskaoutis, D. G., Kambezidis, H. D., Hatzianastassiou, N., Kosmopoulos, P. G. and Badarinath, K. V. S.: Aerosol climatology: on the discrimination of aerosol types over four AERONET sites, Atmos. Chem. Phys. Discuss., 7, 6357-6411, 2007, http://www.atmos-chem-phys-discuss.net/7/6357/2007/.

Kaufman, Y. J.: Aerosol optical thickness and atmospheric path radiance, J. Geophys. Res., 98(D2), 2677-2692, 1993.

Kazadzis, S., Bais, A., Amiridis, V., Balis, D., Meleti, C., Kouremeti, N., Zerefos, C. S., Rapsomanikis, S., Petrakakis, M., and Kelesis, A.: Nine years of UV aerosol optical depth measurements at Thessaloniki, Greece, Atmos. Chem. Phys., 7(8), 2091-2101, 2007.

Kim, S. W., Yoon, S. C., Kim, J. and Kim, S. Y.: Seasonal and monthly variations of columnar aerosol optical properties over east Asia determined from multi-year MODIS, LIDAR, and AERONET Sun/sky radiometer measurements, Atmos. Environ., 41(8), 1634-1651, 2007.

Kinne, S.: Climatologies of cloud related aerosols- part 1 particle number and size, Clouds in the perturbed climate system, edited by Heintzenberg, J. and Charlson, J., ISBN: 978-0-262-01287-4, 2009.

Kubilay, N., Nickovic, S., Moulin, C., and Dulac, F.: An illustration of the transport and deposition of mineral dust onto the eastern Mediterranean, Atmos. Environ., 34, 1293-1303, 2000.

Kubilay, N., Cokacar, T., and Oguz, T.: Optical properties of mineral dust outbreaks over the northeastern Mediterranean, J. Geophys. Res., 108(D21), 4666, doi:10.1029/2003JD003798, 2003.

Lyamani, H., Olmo, F. J., and Alados-Arboledas, L.: Saharan dust outbreak over southeastern Spain as detected by sun photometer, Atmos. Environ., 39(38), 7276-7284, 2005.

Lelieveld, J., Berresheim, H., Borrmann, S., Crutzen, P. J., Dentener, F. J., Fischer, H., Feichter, J., Flatau, P. J., Heland, J., Holzinger, R., Korrmann, R., Lawrence, M. G., Levin, Z., Markowicz, K. M., Mihalopoulos, N., Minikin, A., Ramanathan, V., Reus, M. d., Roelofs, G. J., Scheeren, H. A., Sciare, J., Schlager, H., Schultz, M., Siegmund, P., Steil, B., Stephanou, E. G., Stier, P., Traub, M., Warneke, C., Williams, J., and Ziereis, H.: Global Air Pollution Crossroads over the Mediterranean, Science, 298(5594), 794-799, 2002. 
Levin, Z., Ganor, E., and Gladstein, V.: The effects of desert particles coated with sulfate on rain formation in the eastern Mediterranean, Appl. Meteorol., 35(9), 1511-1523, 1996.

Liu, M., Westphal, D. L., Holt, T. R., and Xu, Q.: Numerical Simulation of a Low-Level Jet over Complex Terrain in Southern Iran, Mon. Weather Rev., 128(5), 1309-1327, 2000.

Martín Vide, J.: Interpretación de los mapas del tiempo, Ketres Editora SA, Barcelona, Spain, 1984.

Middleton, N. J. and Goudie, A. S.: Saharan dust: sources and trajectories, Trans. Inst. Br. Geogr., 26(2), 165, 2001.

Mona, L., Amodeo, A., Pandolfi, M., and Pappalardo, G.: Saharan dust intrusions in the Mediterranean area: Three years of Raman lidar measurements, J. Geophys. Res., 111(D16), D16203, doi:10.1029/2005JD006569, 2006.

Moulin, C., Lambert, C. E., Dayan, U., Masson, V., Ramonet, M., Bousquet, P., Legrand, M., Balkanski, Y. J., Guelle, W., Marticorena, B., Bergametti, G., and Dulac, F.: Satellite climatology of African dust transport in the Mediterranean atmosphere, J. Geophys. Res., 103(D11), 13137-13144, 1998.

O’Neill, N. T., Dubovik, O., and Eck, T. F.: A modified Angstrom coefficient for the characterization of sub-micron aerosols, App. Opt., 40(14), 2368-2375, 2001.

O'Neill, N. T., Eck, T. F., Smirnov, A., Holben, B. N., and Thulasiraman, S.: Spectral discrimination of coarse and fine mode optical depth, J. Geophys. Res., 108, 4559, 2003.

O’Neill, N. T., Smirnov, A., Holben, B., and Thulasiraman, S.: Recent changes to the coarse/fine mode optical depth deconvolution algorithm, AERONET Technical memo, http://aeronet.gsfc.nasa. gov/new_web/PDF/tauf_tauc_technical_memo1.pdf, 2005.

O'Neill, N. T.: Comment on "Classification of aerosol properties derived from AERONET direct sun data" by G. P. Gobbi et al. (2007)", Atmos. Chem. Phys. Discuss., 9, 175-182, 2009, http://www.atmos-chem-phys-discuss.net/9/175/2009/.

Ogunjobi, K., Ajayi, V., Balogun, I., Omotosho, J., and He, Z.: The synoptic and optical characteristics of the harmattan dust spells over Nigeria, Theor. Appl. Climatol., 93(1), 91-105, 2008.

Pace, G., Sarra, A. d., Meloni, D., Piacentino, S., and Chamard, P.: Aerosol optical properties at Lampedusa (Central Mediterranean). 1. Influence of transport and identification of different aerosol types, Atmos. Chem. Phys., 6, 697-713, 2006, http://www.atmos-chem-phys.net/6/697/2006/.

Pérez, C., Sicard, M., Jorba, O., Comerón, A., and Baldasano, J. M.: Summertime re-circulations of air pollutants over the northeastern Iberian coast observed from systematic EARLINET lidar measurements in Barcelona, Atmos. Environ., 38, 3983-4000, 2004.

Perrone, M. R., Santese, M., Tafuro, A. M., Holben, B., and Smirnov, A.: Aerosol load characterization over South-East Italy for one year of AERONET sun-photometer measurements, Atmos. Res., 75(1-2), 111-133, 2005.

Prospero, J.M., Schmitt, R., Cuevas, E., Savoie, D., Graustein, W., Turekian, K., Volz-Thomas, A., Diaz, A., Oltmans, S., and LevyII, H.: Temporal Variability of Summer-time Ozone and Aerosols in the Free Troposphere over the Eastern North Atlantic, J. Geophys. Res. Lett., 22, 21, 2925-2928, 1995.

Prospero, J. M., Ginoux, P., Torres, O., Nicholson, S. E., and Gill, T. E.: Environmental characterization of global sources of atmospheric soil dust identified with the nimbus 7 total ozone mapping spectrometer (TOMS) absorbing aerosol product, Rev. Geo- phys., 40(1), 1002, doi:10.1029/2000RG000095, 2002.

Querol, X., Alastuey, A., Rodríguez, S., Viana, M., Artiano, B., Salvador, P., Mantilla, E., Santos, S. G. d., Patier, R. F., Rosa, J. d. L., Campa, A. S. d. 1., Menendez, M., and Gil, J. J.: Levels of particulate matter in rural, urban and industrial sites in Spain, Sci. Total Environ., 334-335, 359-376, 2004.

Reid, J. S., Eck, T. F., Christopher, S. A., Hobbs, P. V., and Holben, B.: Use of the Ångstrom exponent to estimate the variability of optical and physical properties of aging smoke particles in Brazil, Geophys. Res., 104(D22), 27473-27490, 1999.

Remer, L. and Kaufman, Y. J.: Dynamic aerosol model- Urban/industrial aerosol, J. Geophys. Res., 103(D12), 1385913871, 1998.

Rodríguez, S. and Guerra, J. C.: Monitoring of ozone in a marine environment in Tenerife (Canary Islands), Atmos. Environ., 135, 1829-1841, 2001.

Rodríguez, S., Querol, X., Alastuey, A., Kallos, G., and Kakaliagou, O.: Saharan dust contributions to $\mathrm{PM}_{10}$ and TSP levels in Southern and Eastern Spain, Atmos. Environ., 35, 2433-2447, 2001.

Rodríguez, S., Cuevas, E., González, Y., Ramos, R., Romero, P.M., Pérez, N., Querol, X., Alastuey, A.: Influence of sea breeze circulation and road traffic emissions on the relationship between particle number, black carbon, $\mathrm{PM}_{1}, \mathrm{PM}_{2.5}$ and $\mathrm{PM}_{2.5-10}$ concentrations in a coastal city, Atmos. Environ., 42 (2008) 65236534, 2008.

Schuster, G. L., Dubovik, O., and Holben, B. N.: Angstrom exponent and bimodal aerosol size distributions, J. Geophys. Res, 111, D07207, doi:10.1029/2005JD006328, 2006.

Sciare, J., Bardouki, H., Moulin, C., and Mihalopoulos, N.: Aerosol sources and their contribution to the chemical composition of aerosols in the Eastern Mediterranean Sea during summertime, Atmos. Chem. Phys., 3, 291-302, 2003,

http://www.atmos-chem-phys.net/3/291/2003/.

Silva, A., Costa, M., Elias, T., Formenti, P., Belo, N., and Pereira, S.: Ground-based aerosol monitoring at Évora, Portugal, Global Change NewsLetter, 56, December 2003.

Smirnov, A., Holben, B. N., Eck, T. F., Dubovik, O. and Slutsker, I.: Cloud screening and quality control algorithms for the AERONET database, Remote Sens. Environ., 73, 337-349, 2000.

Smirnov, A., Holben, B. N., Eck, T. F., Slutsker, I., Chatenet, B. and Pinker, R. T.: Diurnal variability of aerosol optical depth observed at AERONET (Aerosol Robotic Network) sites, J. Geophys. Res. Lett., 29(23), 2115, doi:10.1029/2002GL016305, 2002a.

Smirnov, A., Holben, B. N., Dubovik, O., O’Neill, N. T., Eck, T. F., Westphal, D. L., Goroch, A. K., Pietras, C., and Slutsker, I.: Atmospheric Aerosol Optical Properties in the Persian Gulf, Atmos. Sci., 59, 620-634, 2002b.

Sultan, B., Labadi, K., Guégan, J.-F., and Janicot, S.: Climate Drives the Meningitis Epidemics Onset in West Africa, PLoS Med 2(1): e6. doi:10.1371/journal.pmed.0020006, 2005.

Toledano, C., Cachorro, V. E., Berjon, A., de Frutos, A. M., Sorribas, M., de la Morena, B. A., and Goloub, P.: Aerosol optical depth and Angstrom exponent climatology at El Arenosillo AERONET site (Huelva, Spain), Q. J. Roy. Meteor. Soc., 133, 795-807, doi:10.1002/qj54, 2007.

Torres, C., Cuevas, E., and Guerra, J. C.: Caracterización de la capa de mezcla marítima y de la atmósfera libre en la región subtrop- 
8283. Basart et al.: Aerosol characterization in Northern Africa, Northeastern Atlantic, Mediterranean Basin and Middle East

ical sobre Canarias., Asemblea Hispano Portuguesa de Geodesia y Geofisica, Valencia, Spain, 2002.

Viana, M., Querol, X., Alastuey, A., Cuevas, E., and Rodríguez, S.: Influence of African dust on the levels of atmospheric particulates in the Canary Islands air quality network, Atmos. Environ., 36, 5861-5875, 2002.
Wagner, F., Bortoli, D., Pereira, S., Costa, M. J., Silva, A. M., Weinzierl, B., Esselborn, M., Petzold, A., Rasp, K., and Heinold, B.: Properties of dust aerosol particles transported to Portugal from the Sahara desert, Tellus B, 61(1), 29-306, 2009. 